\title{
Sox2 Sustains Recruitment of Oligodendrocyte Progenitor Cells following CNS Demyelination and Primes Them for Differentiation during Remyelination
}

\author{
Chao Zhao, ${ }^{1}$ Dan Ma, ${ }^{1}$ Malgorzata Zawadzka, ${ }^{1}$ Stephen P. J. Fancy, ${ }^{1}$ Lowri Elis-Williams, ${ }^{1}$ Guy Bouvier, ${ }^{1}$ \\ - $\mathrm{J}$ ohn H. Stockley, ${ }^{1}$ Glaucia Monteiro de Castro, ${ }^{1}$ Bowei Wang, ${ }^{1}$ Sabrina Jacobs, ${ }^{1}$ Patrizia Casaccia, ${ }^{2}$ \\ and Robin J. M. Franklin ${ }^{1}$ \\ ${ }^{1}$ Wellcome Trust-Medical Research Council Stem Cell Institute and Department of Clinical Neurosciences, University of Cambridge, Cambridge Biomedical \\ Campus, Cambridge CB2 0AH, United Kingdom, and 2Department of Neuroscience and Friedman Brain Institute, Icahn School of Medicine at Mount Sinai, \\ New York, New York 10029-6574
}

The Sox family of transcription factors have been widely studied in the context of oligodendrocyte development. However, comparatively little is known about the role of Sox2, especially during CNS remyelination. Here we show that the expression of Sox 2 occurs in oligodendrocyte progenitor cells (OPCs) in rodent models during myelination and in activated adult OPCs responding to demyelination, and is also detected in multiple sclerosis lesions. In normal adult white matter of both mice and rats, it is neither expressed by adult OPCs nor by oligodendrocytes (although it is expressed by a subpopulation of adult astrocytes). Overexpression of Sox 2 in rat OPCs in vitro maintains the cells in a proliferative state and inhibits differentiation, while Sox 2 knockout results in decreased OPC proliferation and survival, suggesting that Sox 2 contributes to the expansion of OPCs during the recruitment phase of remyelination. Loss of function in cultured mouse OPCs also results in an impaired ability to undergo normal differentiation in response to differentiation signals, suggesting that Sox2 expression in activated OPCs also primes these cells to eventually undergo differentiation. In vivo studies on remyelination following experimental toxin-induced demyelination in mice with inducible loss of Sox 2 revealed impaired remyelination, which was largely due to a profound attenuation of OPC recruitment and likely also due to impaired differentiation. Our results reveal a key role of Sox2 expression in OPCs responding to demyelination, enabling them to effectively contribute to remyelination.

Key words: demyelination; oligodendrocyte progenitor cells; remyelination; Sox2

Significance Statement

Understanding the mechanisms of CNS remyelination is central to developing effective means by which this process can be therapeutically enhanced in chronic demyelinating diseases such as multiple sclerosis. In this study, we describe the role of Sox2, a transcription factor widely implicated in stem cell biology, in CNS myelination and remyelination. We show how Sox 2 is expressed in oligodendrocyte progenitor cells (OPCs) preparing to undergo differentiation, allowing them to undergo proliferation and priming them for subsequent differentiation. Although Sox 2 is unlikely to be a direct therapeutic target, these data nevertheless provide more information on how OPC differentiation is controlled and therefore enriches our understanding of this important CNS regenerative process.

\section{Introduction}

Remyelination is a rare example of regeneration within the adult mammalian CNS in which new myelin sheaths are made by oli-

Received Sept. 1, 2014; revised May 27, 2015; accepted June 21, 2015.

Author contributions: C.Z. and R.J.M.F. designed research; C.Z., D.M., S.P.J.F., L.E.-W., G.B., J.H.S., G.M.d.C., B.W., and S.J. performed research; M.Z. and P.C. contributed unpublished reagents/analytic tools; C.Z., D.M., and P.C. analyzed data; C.Z. and R.J.M.F. wrote the paper.

This work was mainly supported by the UK Multiple Sclerosis Society and partially supported by NIH/NINDS grant R37 NS042925. We thank Daniel Morrison and Mike Peacock for help with electron microscopy. We also thank Dr. Emily Harrington for advice in mouse oligodendrocyte progenitor cell isolation. As well, we thank the following individuals for providing the transgenic mouse lines used in this study: Dr. Silvia Nicolis for floxed Sox2 mouse line; Drs. Ryan Driskell and Fiona Watts for help and advice in rederivation; Professor William D. Richardson for Pdgfra-creER ${ }^{T 2}$ and Sox $10-$ icreER $^{T 2}$ mouse godendrocytes generated from a population of multipotent CNS progenitor cells, commonly called oligodendrocyte progenitor cells (OPCs; Zhao et al., 2005; Franklin and Gallo, 2014). OPCs, which are abundant throughout the adult CNS, respond to de-

lines; and Dr. Frank Kirchhoff for Gfap-creER ${ }^{T 2}$ :Rosa26floxedSTOP-YFP line. The Rosa26floxedSTOP-fGFP was a gift from Dr. Emma Rawlins. We also thank Dr. Michael Wegner for his gift of plasmids for making cRNA probes for detecting Sox protein transcripts by in situ hybridization.

Correspondence should be addressed to either Robin J. M. Franklin or Chao Zhao, Wellcome Trust-Medical Research Council, Cambridge Stem Cell Institute and Department of Clinical Neurosciences, University of Cambridge, Clifford Allbutt Building, Cambridge Biomedical Campus, Cambridge CB20AH,UK, E-mail:rj1000@cam.ac.uk or_213@cam.ac.uk.

DOl:10.1523/JNEUROSCI.3655-14.2015

Copyright $\odot 2015$ the authors $\quad 0270-6474 / 15 / 3511482-018 \$ 15.00 / 0$ 
myelinating injury by first undergoing activation, colonization of the demyelinated area by proliferation and migration, and eventually differentiation into new myelin-forming oligodendrocytes (Franklin and ffrench-Constant, 2008; Moyon et al., 2015). Critical to this process is the switch from a proliferative/migratory state to the exiting from the cell cycle and differentiation into a nondividing, nonmigratory mature oligodendrocyte. In both developmental myelination and remyelination, the OPC is guided through these mutually exclusive phases of proliferation and differentiation by a complex network of transcription factors, many of which have been identified, although the nature of their interactions remains incompletely understood (Wegner, 2000, Wegner and Stolt, 2005; Emery, 2010; Fancy et al., 2011; Swiss et al., 2011).

A transcription factors whose expression is increased following OPC activation is the HMG family SOX (sex determining region Y box) member Sox2. This transcription factor has been extensively studied in stem cell and developmental biology. Sox2 is a master regulator of embryonic stem cells, maintaining selfrenewal and multipotency (Avilion et al., 2003), and is one of the four transcription factors originally associated with reprogramming somatic cells to a pluripotent state (Takahashi and Yamanaka, 2006, Takahashi et al., 2007). In the nervous system, Sox2 is involved in both developmental neurogenesis (Pevny and Nicolis, 2010) and adult neurogenesis (Bylund et al., 2003; Graham et al., 2003; Ferri et al., 2004; Episkopou, 2005).

Sox 2 was first described in the context of the oligodendrocyte lineage in cultured OPCs, where its induction by platelet-derived growth factor (PDGF) and bone morphogenetic protein 2 is associated with converting OPCs into multipotent "stem cell-like cells" (Kondo and Raff, 2000, 2004). Subsequently, Sox2 was identified as an OPC gene whose expression was subject to the same epigenetic control as other OPC differentiation inhibiting transcription factors (Shen et al., 2008). However, a recent article (Hoffmann et al., 2014) revealed an unexpected role for Sox 2 in the induction rather than the inhibition of oligodendrocyte differentiation (via the suppression of miR145). Although the role of other Sox proteins in oligodendrocytes has been widely studied (Stolt et al., 2002; Sohn et al., 2006; Finzsch et al., 2008; Chew and Gallo, 2009; Molofsky et al., 2013), the role of Sox2 in oligodendrocyte biology, and especially in remyelination, is incompletely understood.

Here, we show that Sox 2 expression occurs in activated OPCs during developmental myelination and remyelination following demyelination, but is expressed in neither adult OPCs in the nondamaged CNS nor by oligodendrocytes following myelination or remyelination. Using both loss-of-function and gain-offunction approaches in cultured OPCs and conditional knockout of Sox2 in transgenic models, we show that Sox 2 promotes OPC proliferation and survival. We conclude that the increased expression of Sox 2 in activated OPCs responding to demyelination is critical for remyelination, maintaining them in a proliferating state and priming them for differentiation.

\section{Materials and Methods}

Focal demyelination in caudal cerebellar peduncle in rats and spinal cord white matter in mice

All animal procedures were performed in compliance with United Kingdom Home Office regulations. The animals were housed under standard laboratory conditions on a $12 \mathrm{~h}$ light/dark cycle with constant access to food and water. For studies involving demyelination, female Sprague Dawley rats (Harlan Laboratories) 8-10 weeks of age were used. Anesthesia was induced and maintained with isoflurane supplemented with buprenorphine $(0.03 \mathrm{mg} / \mathrm{kg}$, i.m. $)$. Demyelination was induced bilater- ally by stereotaxic injection of $4 \mu \mathrm{l}$ of $0.01 \%$ ethidium bromide (EB) into the caudal cerebellar peduncles (CCPs), as previously described (Woodruff and Franklin, 1999). EB was delivered at a rate of $\sim 1 \mu \mathrm{l} / \mathrm{min}$, and the injection needle remained in position for $4 \mathrm{~min}$. Controls received an injection of an equal volume of saline. Mouse demyelinating lesions were created in ventral spinal cord white matter by direct injection of $1 \%$ lysolecithin, as described previously (Zhao et al., 2008; Fancy et al., 2008) using both male and female mice aged between 9 and 11 weeks. For cell proliferation assays in vivo, mouse was provided with 5-ethynyl-2'deoxyuridine (EdU; $0.2 \mathrm{mg} / \mathrm{ml}$; Life Technologies) in the drinking water for $4 \mathrm{~d}$ following demyelination.

\section{Tamoxifen-induced recombination in transgenic mice}

For fate mapping, transgenic mouse lines expressing inducible cre recombinase in defined cell types-Pdgfra-cerER ${ }^{T 2}$, Sox10-icreER ${ }^{T 2}$ mice for OPCs and oligodendrocyte lineage cells, were provided by Professor W. Richardson (University College London, London, UK), and Gfap$\mathrm{creER}^{T 2}$ mice for astrocytes were provided by Dr. F. Kirchoff (University of Göttingen, Göttingen, Germany; Hirrlinger et al., 2006; Rivers et al., 2008; McKenzie et al., 2014). Sox2 promoter-driven inducible Cre mice [Sox2-creER ${ }^{T 2}$ (http://jaxmice.jax.org/strain/017593.html)] and actin promoter-driven Cre line [Cag-creER (http://jaxmice.jax.org/strain/ 004682.html)] were obtained from The Jackson Laboratory (Jaxmice). For OPC fate mapping, homozygous or heterozygous Cre mice were crossed with homozygous Rosa26-floxedSTOP-YFP reporters to generate double-heterozygous offspring for analysis (Rivers et al., 2008). For GFAP fate mapping, double-homozygous mice (Gfap-creER ${ }^{T 2}$ :Rosa26floxedSTOP-YFP) were used. For Sox2 fate mapping, double-heterozygous mice were used, except that the reporter line expressed farnasylated green fluorescent protein (fGFP) rather than yellow fluorescent protein (YFP), and was provided by Dr. E Rawlins (University of Cambridge, Cambridge, UK). For conditional Sox2 knock-out experiments, mice expressing loxP sites flanked Sox 2 gene (Sox $2^{f l f l}$; provided by Dr. S. Nicolis, University of Milan, Milan, Italy) were crossed with the $\mathrm{creER}{ }^{T 2}$ lines to produce heterozyous $c r e E R^{T 2}$ and homozygous Sox $2^{f l / f l}$. The resulting Sox 10-icreER ${ }^{T 2}$ :Sox $2^{f l / f l}$ and Cag-CreER:Sox $2^{l / f l}$ mice were used.

Cre recombination was induced according to the protocols previously described with minor modifications (Leone et al., 2003; Pohl et al., 2011). Briefly, tamoxifen (Sigma-Aldrich), dissolved in corn oil containing 10\% ethanol, was given to adult mice at 8-9 weeks of age by intraperitoneal injection daily for 5 consecutive days, at $100 \mathrm{mg} / \mathrm{kg}$ body weight. This was stopped $5 \mathrm{~d}$ before inducing demyelination. Control animals were agematched, non-cre-expressing animals with the same genetic background; in many cases, littermates received identical doses of tamoxifen. Oral delivery for tamoxifen via gavage was used in some fate-mapping experiments, as described previously (Zawadzka et al., 2010). Newborn mice received tamoxifen at dosage of $0.1 \mathrm{mg}$ in $50 \mu \mathrm{l}$ of corn oil per mouse, from postnatal day 1 (P1) to $\mathrm{P} 3$ at the same time each day. In adult Gfap-creER ${ }^{T 2}$ :Sox $2^{f l f l}$ mice, nearly $80 \%$ of GFAP-expressing cells were labeled with YFP. In the Cag-creER:Sox $2^{f l / f l}$ line, there was $>90 \%$ reduction of Sox2-expressing cells in the spinal cord. The Sox10-icreER $R^{T 2}$ : Sox $2^{f f l}$ line also produced $>90 \%$ efficiency in Sox 2 ablation in oligodendrocyte lineage cells within areas of demyelination in spinal cord.

\section{Tissue processing}

Animals were terminally anesthetized with pentobarbitone and perfused through the left ventricle with $4 \%(\mathrm{w} / \mathrm{v})$ paraformaldehyde (PFA) in PBS, $\mathrm{pH} 7.4$, for cryosectioning. PFA fixed tissue containing a lesion was dissected, post-fixed in 4\% PFA for 2-4 h, then immersed in 20\% sucrose solution prepared with PBS for $48 \mathrm{~h}$ before embedding with optimal cutting temperature compound (Bright Instruments). Coronal frozen sections were thaw mounted onto poly-L-lysine-coated slides and stored at $-80^{\circ} \mathrm{C}$ until further use.

\section{Multiple sclerosis tissue}

Postmortem human brain tissue from six cases was obtained from the UK Multiple Sclerosis Tissue Bank. Inflammation was characterized by immunochemistry with LN3 (HLA-DR) antibody and myelin loss by Luxol fast blue histology. 
In situ hybridization with $c R N A$ probes

Plasmid containing proteolipid protein (PLP)-1 cDNA was a gift from Professor I. Griffiths (University of Glasgow, Glagsow, UK). Plasmid containing full-length Sox2 cDNA was obtained from Dr. M. Wegner (University of Erlangen-Nuremberg, Erlangen-Nuremberg, Germany). Rat platelet-derived growth factor receptor- $\alpha$ (PDGFRA) cDNA in plasmid pGEM was provided by Dr. N. Pringle and Professor W. Richardson (University College London, London, UK). Details of the in situ hybridization (ISH) procedure using digoxigenin (DIG)-labeled cRNA probes have been previously described (Fancy et al., 2004; Zhao et al., 2006). To label cRNA probes, following linearization of plasmids with appropriate restriction enzyme and DIG or fluorescein isothiocyanate (FITC), labeled antisense probes were synthesized using the DIG RNA labeling kit (Roche) with suitable RNA polymerases. The target mRNA-expressing cells were visualized as a dark purple deposition with NBT/BCIP-alkaline phosphatase combination. Double labeling with two color in situ hybridization has been described previously (Zhao et al., 2008). In brief, a mixture of two different target mRNA probes labeled with DIG and FITC, respectively, was used for hybridization with the same subsequent procedure of single color in situ hybridization. After visualization of first target mRNA using NBT/BCIP, the alkaline phosphatase is inactivated by incubation of the slides at $65^{\circ} \mathrm{C}$ then $0.1 \mathrm{M}$ glycine, $\mathrm{pH} 2.2$, for $30 \mathrm{~min}$, respectively. Sections were then incubated with alkaline phosphataseconjugated antibody specific to the label of the second probe. The second target mRNA was visualized by incubating with INT/BCIP, which formed a magenta/brown deposition around the targets.

\section{Immunohistochemistry}

Frozen sections, or fixed cultured cells, were rinsed in PBS, permeabilized and blocked with PBS containing 0.3\% (v/v) Triton X-100 and 5\% (v/v) normal donkey serum in PBS for $1 \mathrm{~h}$ at room temperature (RT; 20$25^{\circ} \mathrm{C}$ ), then incubated for $12-16 \mathrm{~h}$ at $4^{\circ} \mathrm{C}$ with primary antibodies followed by incubation with fluorophore-conjugated secondary antibodies for $1 \mathrm{~h}$ at RT. Primary and secondary antibodies were diluted in PBS containing $5 \%$ donkey serum and $0.1 \%$ Triton X-100. For double labeling, the above procedure was repeated sequentially using primary antibodies from different animal species and distinguishable fluorophore-conjugated secondary antibodies. Cell nuclei were counterstained with DNA fluorescent dye Hoechst 33342 (Sigma-Aldrich) in PBS. Stained tissue or cells were coverslipped in FluoSave mounting medium (Millipore) and examined on either a Zeiss Axio Observer Fluorescence Microscope or a Leica SP5 Laser Scanning Confocal Microscope. The following primary antibodies were used: Sox2 (goat, 1:500; Santa Cruz Biotechnology); GFP (goat, 1:1000; rabbit, 1:1000; Abcam); NG2 (rabbit, 1:500; Millipore), Nkx2.2 (mouse; Developmental Studies Hybridoma Bank, University of Iowa, Iowa City, IA); Olig2 (rabbit, 1:1000; Millipore); Olig2 (goat, 1:200; R\&D Systems); myelin basic protein (MBP; rat, 1:200; Serotec); GFAP (rabbit, 1:1000; Dako); Transferrin (rabbit, 1:1000; Abcam); CC-1 (mouse, 1:100; Calbiochem); Olig1 (rabbit, 1:2000; a gift from Dr. John Alberta, Dana-Farber Cancer Institute); periaxin (rabbit, 1:3000; a gift from Professor Peter Brophy, University of Edinburgh); Ki67 (rabbit, 1:500; Abcam); and ALDH1L1 (mouse; NeuroMab). The secondary antibodies used were as follows: Alexa Fluor 488-, 594-, 633-conjugated donkey antibodies against mouse, rat, rabbit, or goat IgG, IgG1, and IgG2b (1:1000; all from Life Technologies). Antigen retrieval with $10 \mathrm{~mm}$ sodium citrate buffer, $\mathrm{pH}$ 6.0, was performed before labeling nuclear antigens. EdU incorporation was visualized using Click-iT EdU Alexa Fluor 488 Imaging Kit (Life Technologies) before immunohistochemistry (IHC). The multiple sclerosis (MS) tissue was paraffin embedded, subjected to biotin-avidin immunostaining techniques for Sox2, and visualized with 3,3'-diaminobenzidine counterstained with hematoxylin.

\section{Isolation and culture of oligodendrocyte progenitor cells from neonatal rats and mice}

Rat oligodendrocyte progenitor cell isolation and transfection. OPCs were isolated from P2 to P3 neonate Sprague Dawley rats by mechanical dissociation of mixed glial cultures as originally described, with some minor modifications (McCarthy and de Vellis, 1980). Microglia were removed by differential adhesion to uncoated plastic Petri dishes (Corning). OPCs present in the supernatant were pelleted by centrifugation $\left(250 \times g_{\max }\right.$ for $8 \mathrm{~min}$ ) and seeded at a density of $1.6 \times 10^{6}$ per T $-75 \mathrm{~cm}^{2}$ flask in OPC medium [DMEM supplemented with Sato's medium, $10 \mathrm{ng} / \mathrm{ml}$ plateletderived growth factor AA (PDGF-AA) and $10 \mathrm{ng} / \mathrm{ml}$ basic fibroblast growth factor]. After $2 \mathrm{~d}$, OPCs were dissociated with $1.6 \mathrm{U} / \mathrm{ml}$ papain (Worthington Biochemical Corporation) and subsequently blocked with $20 \%$ FCS in DMEM. A total of $5.5 \times 10^{6}$ OPCs were transfected with $4 \mu \mathrm{g}$ of DNA using the Rat Oligodendrocyte Kit and Amaxa Nucleofector II device, according to the manufacturer instructions (Lonza). Plasmid pCDH.CMV-Sox2:EF1-GFP (System Biosciences) was constructed to contain the full-length mouse Sox 2 gene driven by constitutive cytomegalovirus (CMV) promoter and a reporter gene expressing GFP controlled by a separate constitutive promoter, elongation factor 1 (EF1). Control plasmid pCDH:EF1-GFP contained only GFP. Following transfection, $6.5 \times 10^{4}$ OPCs were plated on poly-D-lysine (PDL)-coated 22-mm-diameter glass coverslips and maintained in OPC medium with growth factors before switching to differentiation medium (OPC medium without growth factors). Cells were fixed with $4 \%$ paraformaldehyde before being analyzed for differentiation by immunostaining for myelin basic protein.

Mouse OPC isolation. Mouse OPCs were isolated from cerebral cortices of mice at age P7-P9 from the transgenic line Cag-creER:Sox $2^{f f l}$. Litters providing OPCs were administered intraperitoneally with tamoxifen at P1-P3, at a concentration of $2 \mathrm{mg} / \mathrm{ml}$, at the same time each day for $3 \mathrm{~d}$. At P5, genotyping was performed to identify the Cre and non-Cre carrier littermates from biopsy samples, which were pooled by genotype for OPC isolation. Recombination in Cre-expressing (knock-out) individuals was confirmed by PCR using primers designed to detect the Sox 2 gene. OPCs were obtained by enzymatic dissociation and subsequent immunopanning, as detailed previously (Harrington et al., 2010). Cells from control and Sox 2 knock-out animals were then seeded in 12-well tissue culture plates coated with PDL (Sigma-Aldrich), at a density of 20,000 per well. OPCs were maintained in serum-free medium containing PDGF-AA and neurotrophin-3 (NT-3), and ciliary neurotrophic factor (CNTF) for $4 \mathrm{~d}$ before being either fixed with $4 \%$ PFA or subjected to the differentiation condition by withdrawing PDGF-AA and NT-3, and adding triiodothyronine (T3). Differentiated cells were fixed at day 3 or 5. The fixed cells were then analyzed by fluorescence immunocytochemistry. The differentiation of OPCs was assessed by morphology or MBP expression, as described by Huang et al. (2011).

The mouse OPC transwell migration assay was adapted from published protocols using rat OPCs (Stoffels et al., 2015). Briefly, immediately after isolation, 30,000 OPCs in $200 \mu \mathrm{l}$ of OPC medium without growth factors were seeded onto a 24-well Millicell hanging cell culture insert ( $8 \mu \mathrm{m}$ polyethylene terephthalate; Millipore), which was placed in a 24-well culture plate containing $700 \mu \mathrm{l}$ of OPC medium with growth factors (i.e., $20 \mathrm{ng} / \mathrm{ml} \mathrm{CNTF,} 20 \mathrm{ng} / \mathrm{ml} \mathrm{NT3}$, and $40 \mathrm{ng} / \mathrm{ml}$ PDGF-AA). The cells were incubated for $4 \mathrm{~h}$, fixed with $4 \%$ PFA, and stained with Hoechst 33342 in PBS. Cells remaining on top of the transwell membrane were removed by swabbing, and the membrane was inversely mounted on slides and coverslipped. Cells that had migrated to the underside of the membrane were imaged from 8-10 random 10× fields (Observer A1 Inverted Microscope, Zeiss), and Hoechst-stained nuclei were counted using the open source software ImageJ.

\section{Electron microscopy analysis}

Animals were perfused with $4 \%$ glutaraldehyde in PBS containing 0.4 $\mathrm{mm} \mathrm{CaCl} 2$. The spinal cord was coronally sliced at $\sim 1 \mathrm{~mm}$ thickness and treated with $2 \%$ osmium tetroxide overnight before being subjected to a standard protocol for epoxy resin embedding (Zhao et al., 2008). Lesions were located on semithin $(1 \mu \mathrm{m})$ sections stained with toluidine blue. Ultrathin sections of the lesion site were cut onto copper grids and stained with uranyl acetate before being examined with a Hitachi H-600 Transmission Electron Microscope. Myelinated and remyelinated axons were analyzed for g-ratio, which was calculated as the diameter of axons divided by the diameter of axons with surrounding myelin sheaths. A total of 100-200 axons from three to four animals in each group are measured for g-ratio. 

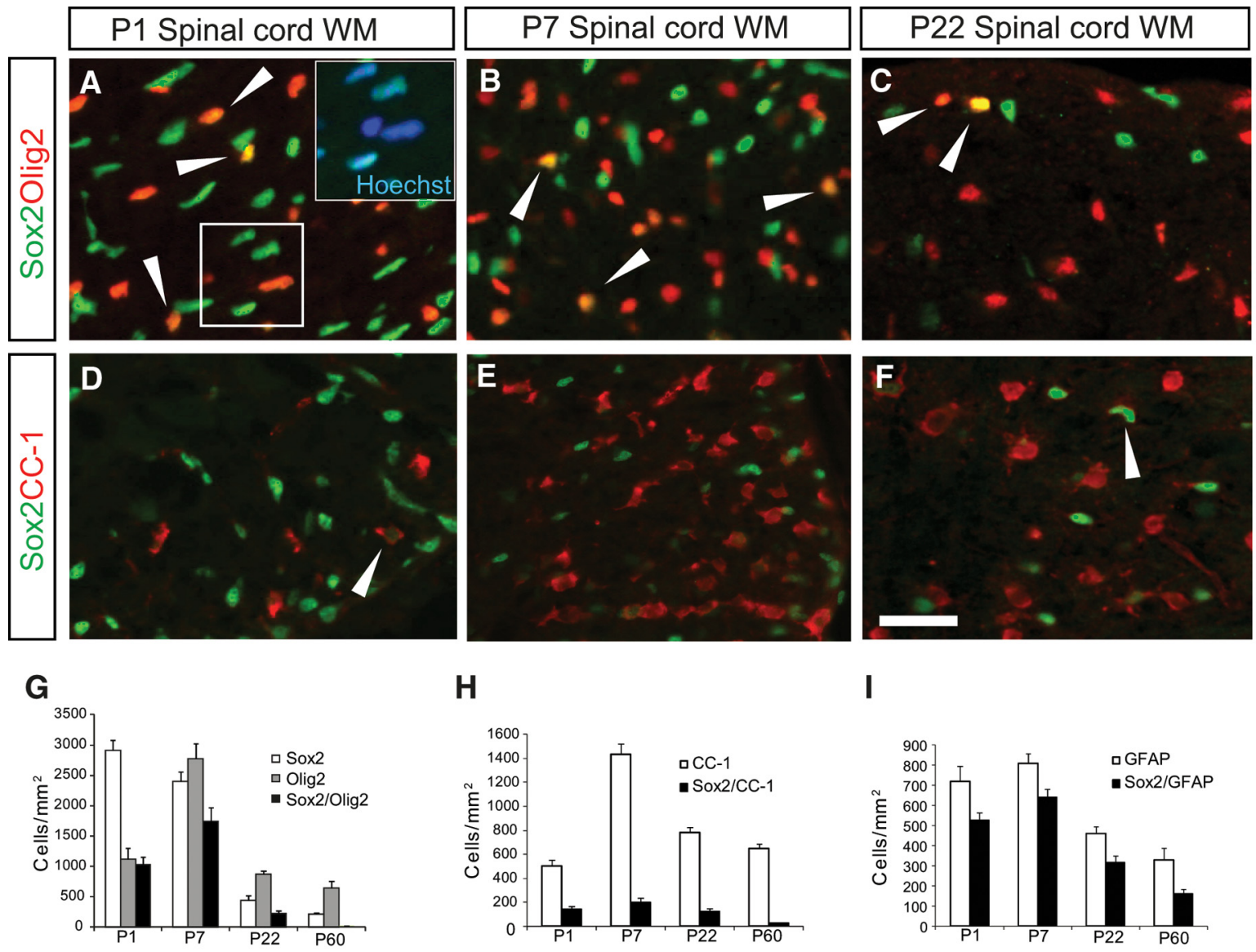

H
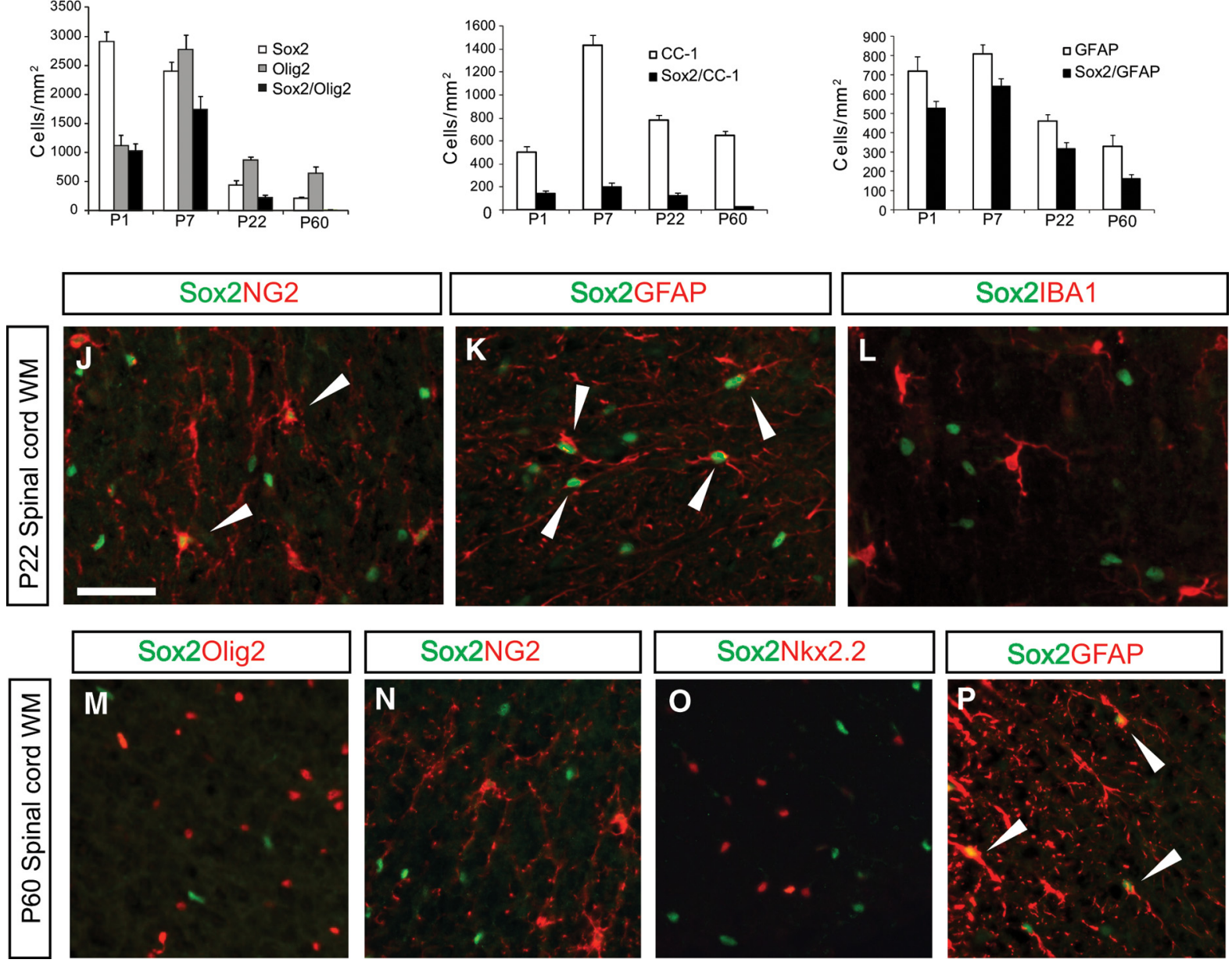

Figure 1. Sox2 is expressed by OPCs during developmental myelination but only in astrocytes in adult white matter (WM). $A-F$, Images show merged fluorescence double immunostaining of mouse transverse sections of ventral spinal cord white matter at P1 $(\boldsymbol{A}, \boldsymbol{D}), \mathrm{P7}(\boldsymbol{B}, \boldsymbol{E})$, and P22 $(\boldsymbol{C}, \boldsymbol{F})$, double labeled with antibodies against Sox2 and oligodendrocyte lineage marker 0lig2 $(\boldsymbol{A}-\boldsymbol{C})$, or Sox2 and mature oligodendrocyte marker APC (CC-1). The inset in $A$ shows the boxed area in the main image, with merged Sox2 and Hoechst 33342 staining indicating nuclear localization. Graphs $\mathbf{G}-\boldsymbol{I}$ represent the quantification of the densities of different cell types that express Sox2 throughout postnatal development in ventral spinal cord white matter. $\boldsymbol{J}-\boldsymbol{P}$, Expression of Sox 2 in mouse spinal cord white matter at P22 $(J-L)$ and P60 $(M-P)$ is further characterized with specific glial markers, and is presented as merged red and green channel images. The arrowheads indicate representatives of dual-labeled cells. Values are the mean \pm SE. $n=4$. Scale bars: (in $\boldsymbol{F}) \boldsymbol{A}-\boldsymbol{F}, 25 \mu \mathrm{m}$; (in $\boldsymbol{J}$ ) $\boldsymbol{J}-\boldsymbol{L}, 40 \mu \mathrm{m} ; \boldsymbol{M}-\boldsymbol{P}, 75 \mu \mathrm{m}$. 
A

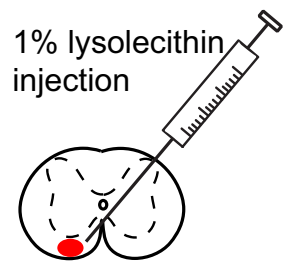

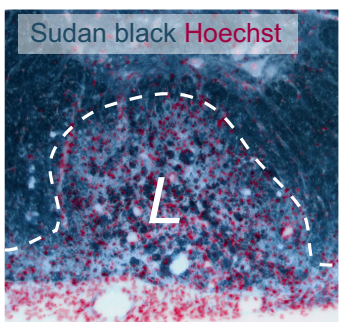
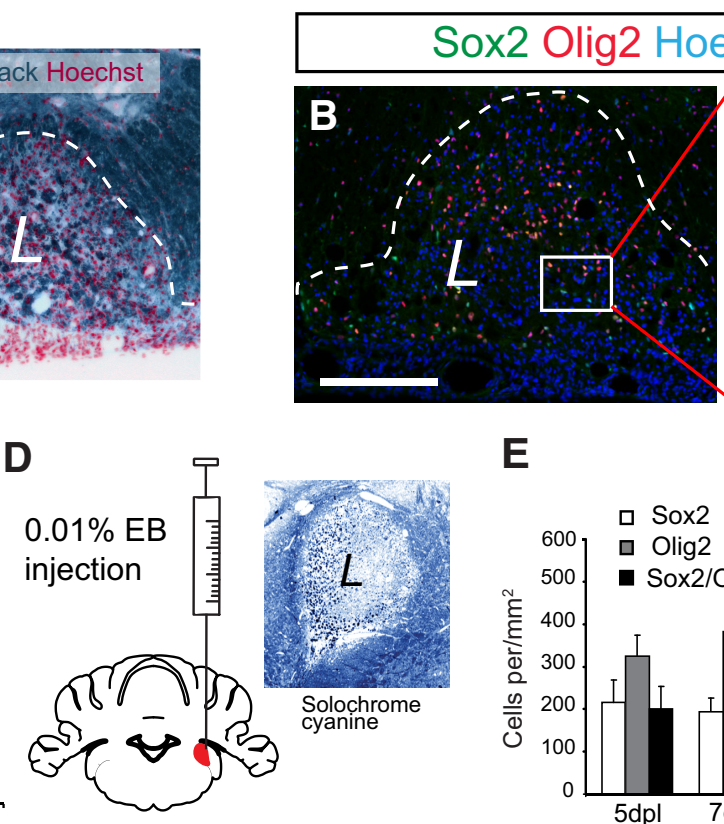

E

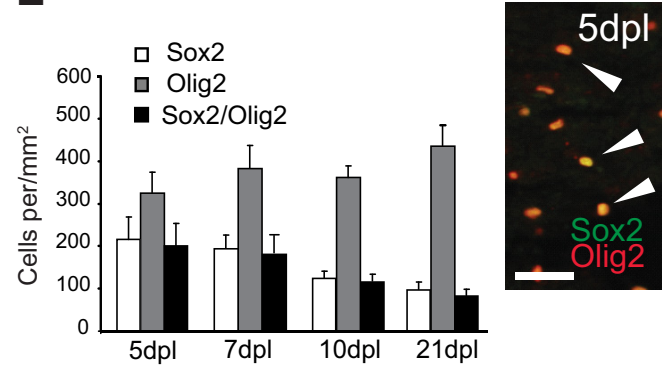

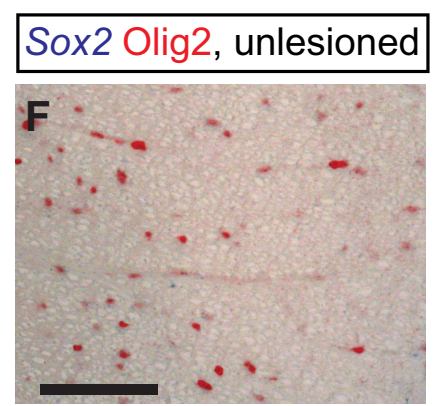
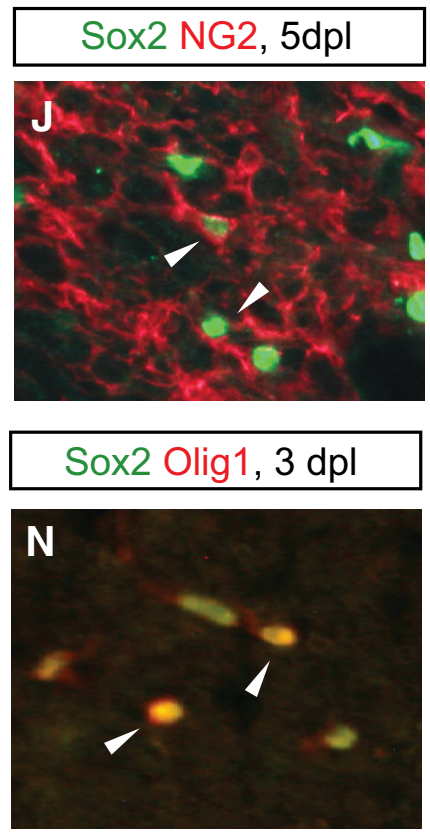
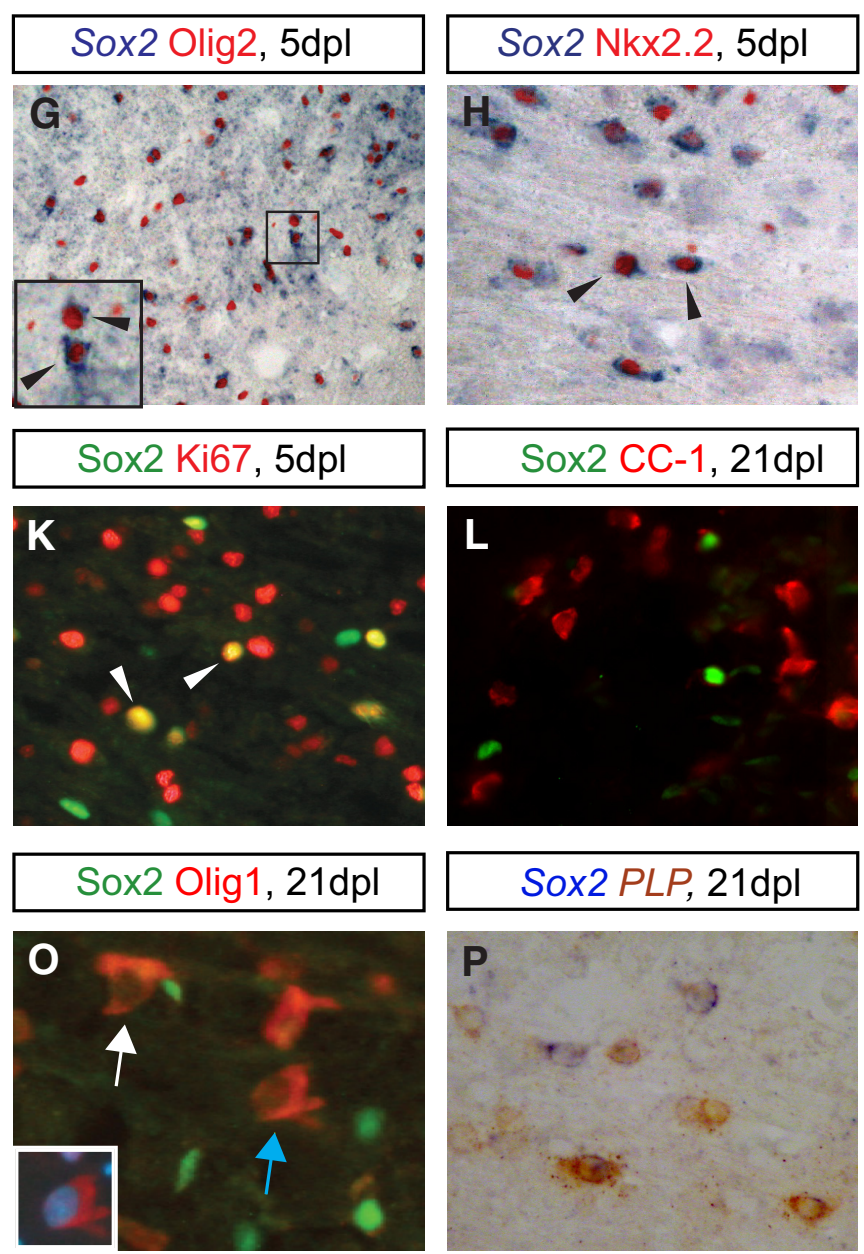
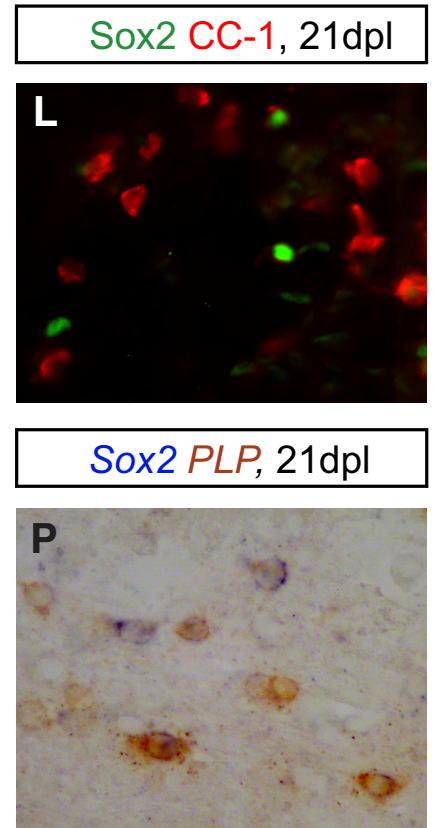
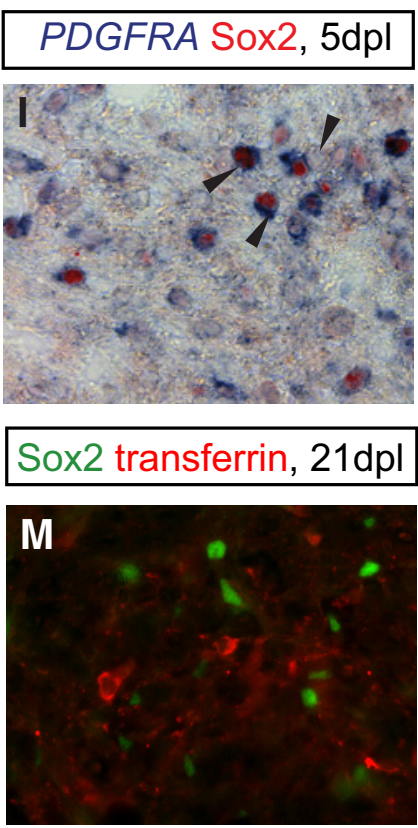

Sox2 periaxin, 21dpl

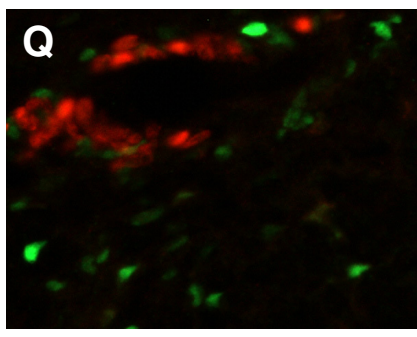

Figure 2. Sox2 is highly expressed in OPCS following lysolecithin-induced demyelination in mouse spinal cord and EB-induced demyelination in rat CCP. A, Mouse spinal cord demyelination model. The location of focal demyelination in the ventral white matter is marked in red. The histological image to the right shows an overlay of images of Sudan black and Hoechst 33342 staining (pseudocolored), indicating the overlap between demyelinated area and increased cellularity. $\boldsymbol{B}$, Merged double-immunofluorescence staining of Sox 2 and 0 lig 2 at $14 \mathrm{dpl}$ : the boxed area to the right highlights Sox2 ${ }^{+}$Olig2 ${ }^{+}$dual-labeled cells (arrowheads). $C$, Sox2 ${ }^{+}$cell and Olig2 ${ }^{+}$cell densities in demyelinated mouse spinal cord. $\boldsymbol{D}$, The rat CCP-EB lesion at the level of paraflocculus of cerebellum (lesion marked in red). The adjacent image shows a demyelination lesion revealed by solochrome cyanine staining at $5 \mathrm{dpl}$ (pale area marked with $L$ ). $\boldsymbol{E}$, Almost all Sox ${ }^{+}$cells in $C(P P$ lesions colocalized with Olig2 (E, image), while the cellular profile $(\boldsymbol{E}$, graph) resembles mouse spinal cord lesions in $\boldsymbol{C}$. $\boldsymbol{F}-\boldsymbol{Q}$, Images from normal $(\boldsymbol{F})$ and (Figure legend continues.) 

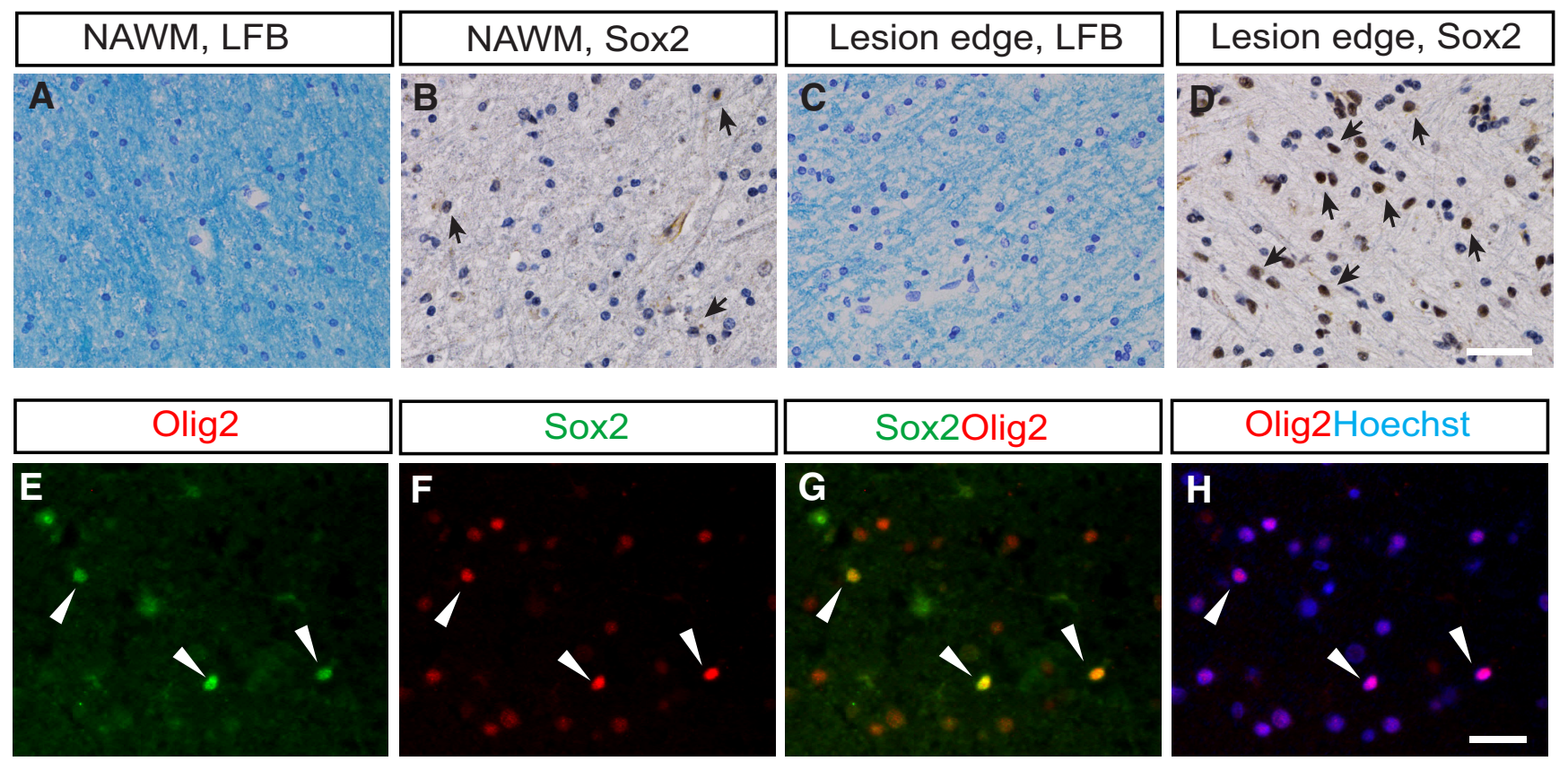

Figure 3. Sox2 can be detected in lesions within MS brains. Sections from postmortem cerebral MS tissue were examined, and demyelinated areas were verified by histology and immunohistochemistry, which revealed chronic plaques with active inflammation at the periphery. $\boldsymbol{A}-\boldsymbol{D}$, The top row illustrates areas of normal-appearing white matter (NAWM; $\boldsymbol{A}, \boldsymbol{B})$ and of the edge of a demyelinated lesion $(\boldsymbol{C}, \boldsymbol{D})$ depicting myelin by Luxol fast blue (LFB; $\boldsymbol{A}, \boldsymbol{C}$ ) and immunostaining for Sox2 (brown; $\boldsymbol{B}, \boldsymbol{D}$ ), counterstained with hematoxylin, with positive nuclei indicated by arrows. The bottom row are images from a lesion edge double stained with Sox2 $(\boldsymbol{E})$ and 0 lig2 $(\boldsymbol{F})$ showing colocalization of the two markers (arrowheads). Scale bars: (in $\boldsymbol{D}) \boldsymbol{A}-\boldsymbol{D}, 100 \mu \mathrm{m}$; (in $\boldsymbol{H}) \boldsymbol{E}-\boldsymbol{H}, 50 \mu \mathrm{m}$.

\section{Quantification and data analysis}

Immunoreactive cells were counted if they were clearly associated with a nucleus. Cell density was obtained from at least three areas on separate sections of unlesioned tissue. For lesions, cells were sampled at random from three to four transverse sections from the central location of the lesion (taken to be the section of the lesion with the largest cross-sectional area). GraphPad Prism and Microsoft Excel software were used for statistical analysis. An unpaired Student's $t$ test was used to compare differences between two groups; statistical significance was set at $p<0.05$.

\section{Results}

Sox 2 is expressed by oligodendrocyte progenitor cells and astrocytes in postnatal CNS but not by oligodendrocytes

We first characterized the expression and distribution of Sox 2 in postnatal and adult mouse spinal cord white matter by immunohistochemistry. At P1 and P7, when myelination is occurring, numerous cells with Sox $2^{+}$nuclei were detected throughout the spinal cord. These were identified by double-immunofluorescence labeling as being Olig $2^{+}, \mathrm{NG}^{+}{ }^{+}$, or $\mathrm{Nkx} 2.2^{+} \mathrm{OPCs}$, or GFAP ${ }^{+}$astrocytes (Fig. 1). No Sox ${ }^{+}$cells were colabeled with the microglia marker IBA-1 (ionized calcium-binding adapter molecule-1; Fig. $1 L)$. By P22, when most spinal cord axons are myelinated, the

(Figure legend continued.) demyelinated areas in rat $(C P(G-J)$ showing overlaid staining of Sox2 with specific markers using either a combination of in situ hybridization and immunofluorescence, double immunofluorescence, or two-color in situ hybridization. Sox2 mRNA is not detectable in normal $C(P(\boldsymbol{F})$, but is strongly expressed at 5 dpl by cells expressing 0 lig2 $(\boldsymbol{G}$; inset shows magnified area), Nkx2.2 (H), PDGFRA (I), and NG2 (J). $\boldsymbol{K}$, Sox2 ${ }^{+}$cells expressing proliferation marker Ki67.L, $M, P, Q, A t 21 \mathrm{dpl}$, Sox2 is rarely colocalized with mature oligodendrocyte markers $C(-1(\boldsymbol{L})$, transferrin $(\boldsymbol{M})$, and PLP mRNA (PLP; $\boldsymbol{P})$, and remyelinating Schwann cell periaxin (Q). Sox2 is colocalized only with nucleus-expressing 0 lig1 at early time points $(\boldsymbol{N}, 3$ $\mathrm{dpl}$ ), but later is separate from cells expressing cytoplasmic 0 lig $1(\mathbf{0})$. Italic image labels signify expression of transcripts. Arrowheads indicate examples of colocalization of two or more markers. The capital $L$ in images marks the area of lesions. Values are shown as the mean \pm SE. $n=$ 4-5. Scale bars: $\boldsymbol{B}, 200 \mu \mathrm{m} ; \boldsymbol{E}, 50 \mu \mathrm{m}$; (in F) $\boldsymbol{F}, \boldsymbol{G}, 100 \mu \mathrm{m} ; \boldsymbol{H}-\mathbf{Q}, 50 \mu \mathrm{m}$. majority of Sox $2^{+}$cells were GFAP ${ }^{+}$astrocytes, with only $25 \%$ of the Olig ${ }^{+}$oligodendrocyte lineage cells continuing to express Sox 2 , among which $15.3 \%$ were CC- $1^{+}$oligodendrocytes (Fig. $1 C, F)$. By P60, very few Olig2 ${ }^{+}$cells expressed Sox 2 , although it continued to be expressed in $\sim 50 \%$ of $\mathrm{GFAP}^{+}$astrocytes (Fig. $1 I, P)$. These data show that as the spinal cord white matter develops there is loss of Sox 2 expression in oligodendrocyte lineage cells, although it continues to be expressed in a subpopulation of astrocytes.

\section{Sox 2 is expressed by OPCs following acute experimental demyelination of adult white matter}

We next examined Sox 2 expression in adult mouse spinal cord white matter following acute focal demyelination induced by the injection of lysolecithin (Fig. 2A). At both 5 and $14 \mathrm{~d}$ postlesion $(\mathrm{dpl})$, time points corresponding to peak OPC recruitment and ongoing differentiation, respectively (Arnett et al., 2004), there were substantial numbers of Sox ${ }^{+}$cells and Olig2 ${ }^{+}$cells within the area of demyelination (Fig. $2 \mathrm{~B}, \mathrm{C}$ ). At $5 \mathrm{dpl}, 40 \%$ of Olig ${ }^{+}$ cells also expressed Sox 2 , although by $14 \mathrm{dpl}$ this proportion had decreased to $26 \%$ and still further to $14 \%$ at $21 \mathrm{dpl}$. Not all Sox 2 cells were colabeled with Olig $2^{+}$; at each time point, upward of $50 \%$ were colabeled with the astrocyte markers GFAP and ALDH1L1 (Cahoy et al., 2008; data not shown).

The expression of Sox 2 in both OPCs and astrocytes generated a high density of Sox $2^{+}$cells within the demyelinated area, which complicated the analysis of Sox 2 expression in oligodendrocyte lineage cells. We therefore turned to a second toxin-induced model of demyelination in which there is greater depletion of astrocytes than occurs following lysolecithin injection. This model involves the injection of $\mathrm{EB}$ and is best characterized in the adult rat CCP (CCP-EB; Woodruff and Franklin, 1999; Fig. 2D). We first performed ISH using digoxigenin-labeled Sox 2 cRNA probes. In normal adult white matter, Sox 2 mRNA expression was below the limit of detection by ISH, but at 5 and $7 \mathrm{dpl}$ large 
A

(a) Tamoxifen

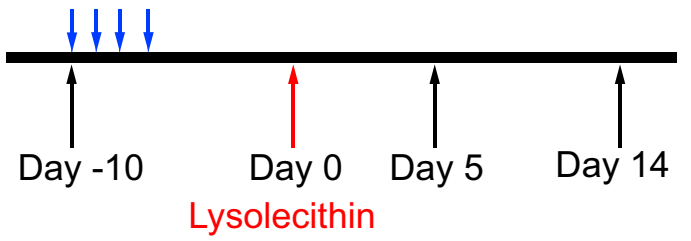

(b)

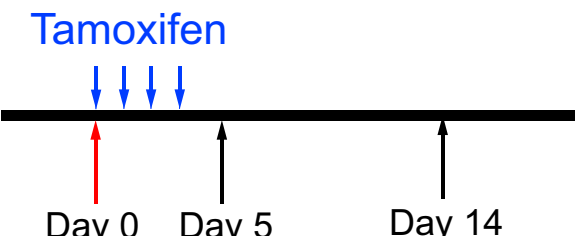

Lysolecithin (c)

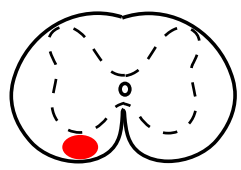

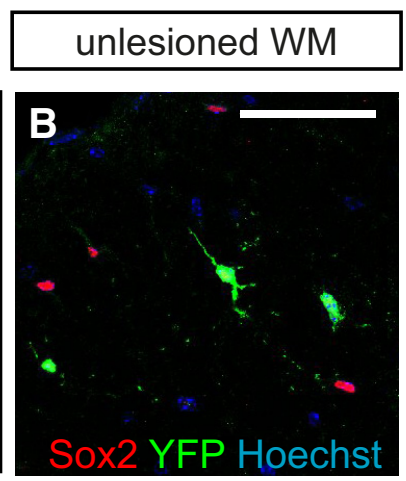
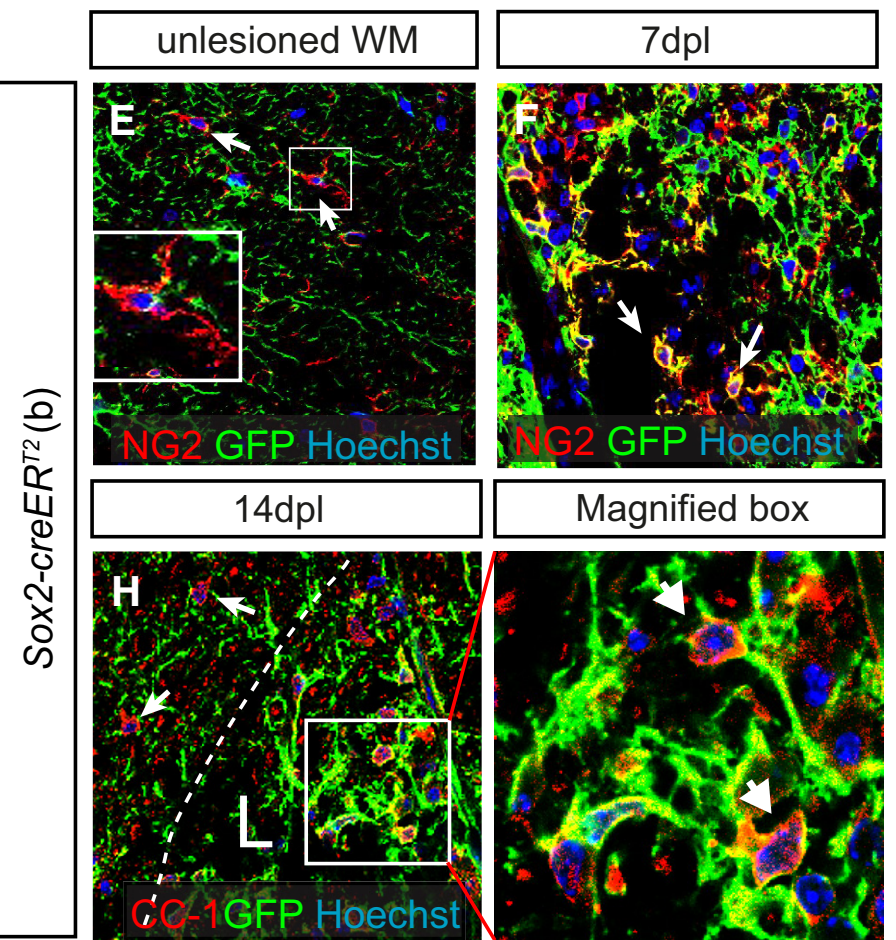
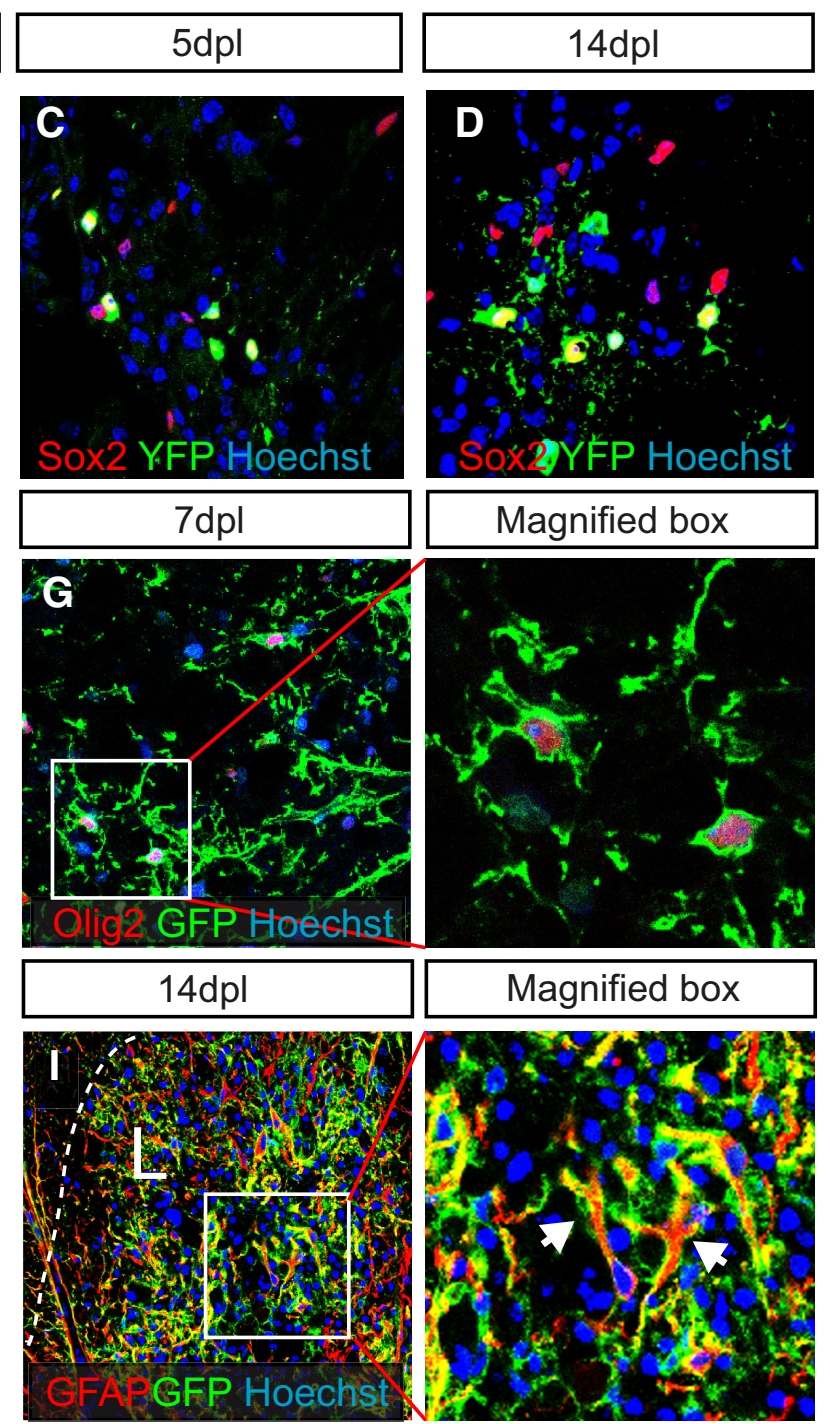

Figure 4. Sox2 expressing OPCs derived from resting OPCs before demyelination give rise to remyelinating oligodendrocytes. Genetic fate-mapping strategy in transgenic mice with tamoxifeninducible (re/LoxP (CreER ${ }^{T 2}$-mediated activation of reporter gene YFP (or farnesylated GFP; see Materials and Methods). Tamoxifen was administered to mice (blue arrows) relative to the demyelination lesion (red arrows) for recombination according to two protocols, as illustrated in $\boldsymbol{A}$, starting either $10 \mathrm{~d}$ before demyelination $(\boldsymbol{A} \boldsymbol{a})$ or on the day of demyelination $(\boldsymbol{A} \boldsymbol{b})$. Focal demyelination lesion in ventral spinal cord was created by the injection of lysolecithin (Ac). Conditional expression of Cre recombinase was controlled by specific promoters, as indicated in the image labels with induction protocols marked in the brackets. $\boldsymbol{B}-\boldsymbol{D}$, Confocal images show overlaid immunostaining of YFP and Sox 2 in the unlesioned white matter ( $\boldsymbol{B}$ ), and areas of demyelinated lesions at both $5 \mathrm{dpl}(\boldsymbol{C})$ and $14 \mathrm{dpl}(\boldsymbol{D})$. $\boldsymbol{E}-\boldsymbol{I}$, Fate mapping of cells expressing Sox2 (Sox2-creER ${ }^{T 2}$ ) with tamoxifen induction immediately following demyelination (Ab). The reporter farnesylated GFP rarely colocalizes with OPC marker NG2 in unlesioned white matter $(\boldsymbol{E})$ but does so in the demyelinated area $(\boldsymbol{F})$. Colocalization of farnesylated GFP was found with oligodendrocyte lineage marker 0lig2 $(\boldsymbol{G})$, mature oligodendrocyte marker $(\mathrm{C}-1(\boldsymbol{H})$, as well as with astrocyte marker $\mathrm{GFAP}(\boldsymbol{K})$ in the demyelinated area. Scale bars: (in $\boldsymbol{B}) \boldsymbol{C}, \boldsymbol{D}, 50 \mu \mathrm{m}$; (in $\boldsymbol{B}) \boldsymbol{B}, \boldsymbol{F}-\boldsymbol{H}, 60 \mu \mathrm{m} ; \boldsymbol{I}, 100 \mu \mathrm{m}$.

numbers of Sox 2 mRNA-expressing cells were detected within the area of demyelination (Fig. $2 F, G$ ). The numbers of these cells progressively decreased at 10 and $21 \mathrm{dpl}$. Sox2-expressing cells were also detected by IHC, where expression was confined to the nucleus. The temporal profile of Sox ${ }^{+}$cells closely resembled that observed for Sox $2^{+} /$Olig2 ${ }^{+}$following lysolecithin-induced demyelination in mice (Fig. 2C,E). Double labeling with IHC or combined ISH/IHC revealed that almost all Sox2-expressing cells also expressed Olig2 and were therefore likely to be cells of the oligodendrocytes lineage, although not all Olig2 ${ }^{+}$cells coexpressed Sox 2 (Fig. 2E). At 5 and $7 \mathrm{dpl}$, when there are few or no oligodendrocytes within the lesion, we identified Sox $2^{+}$cells as being OPCs by colabeling with the OPC markers NG2, Nkx2.2, and PDGFRA mRNA (Fig. $2 H-J$ ). Approximately $50 \%$ of Sox 2 
A

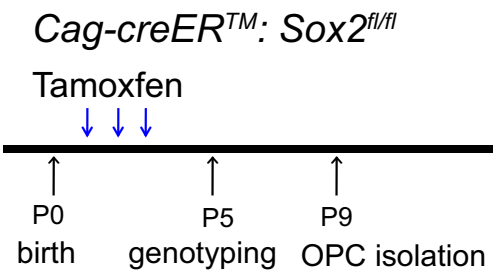

D

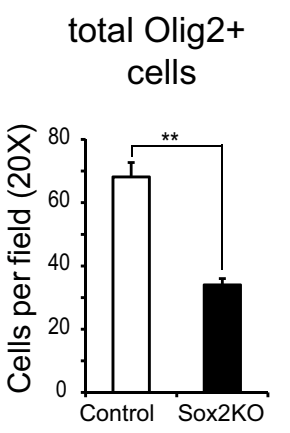

E

proliferating Olig2+ cells

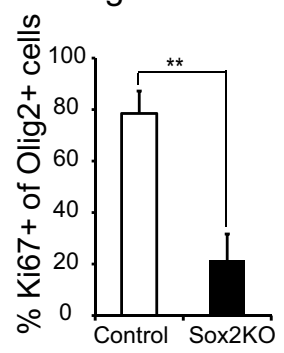

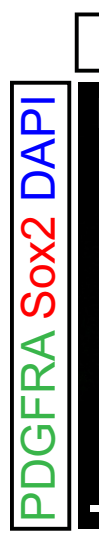
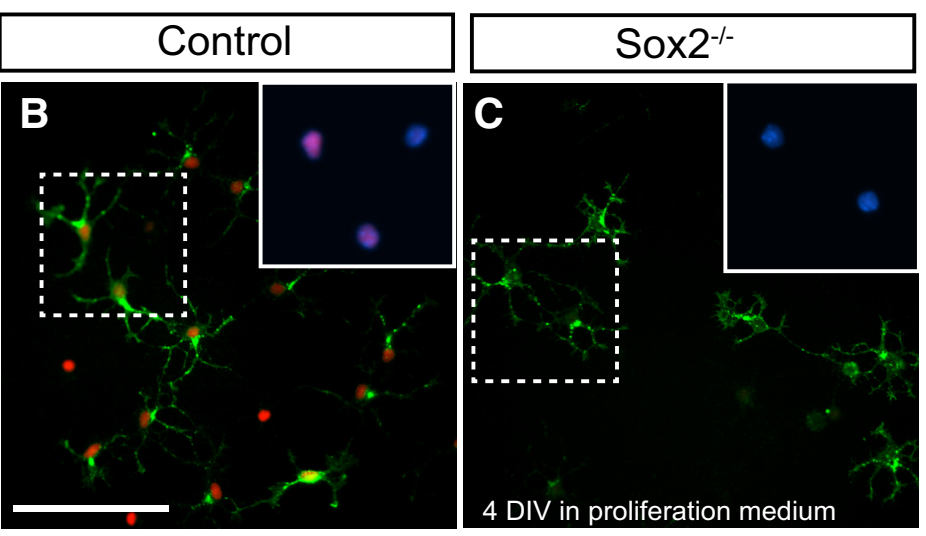

$\mathbf{F}$

G

Transwell Migration

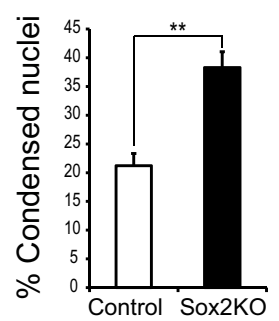

H

Proportion MBP+

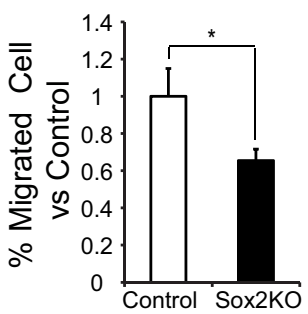

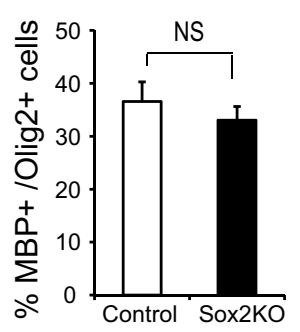

I

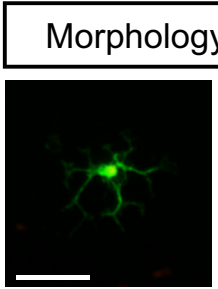

Simple

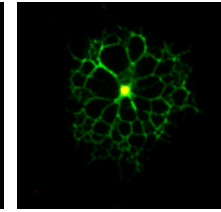

Complex

membrane
J

Day 3 differentiation

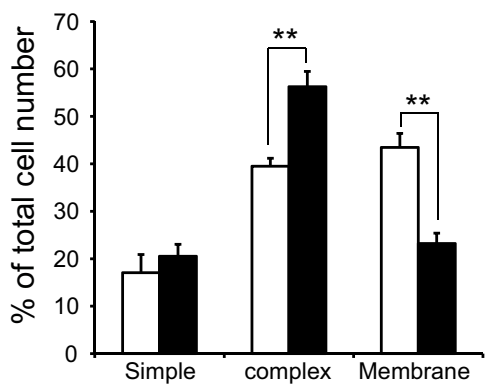

K Day 5 differentiation

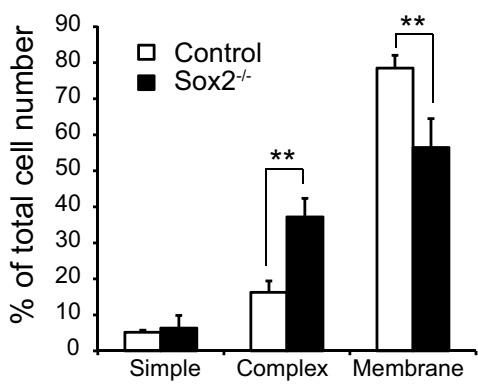

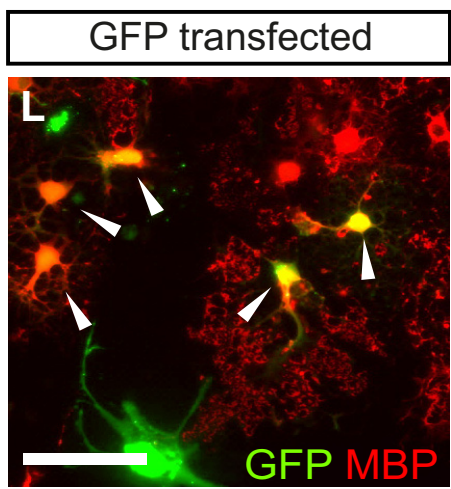

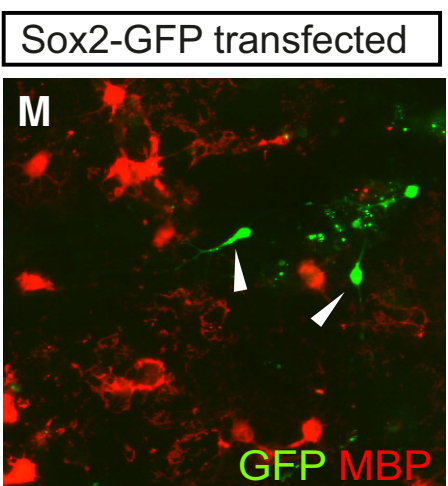

$\mathbf{N}$

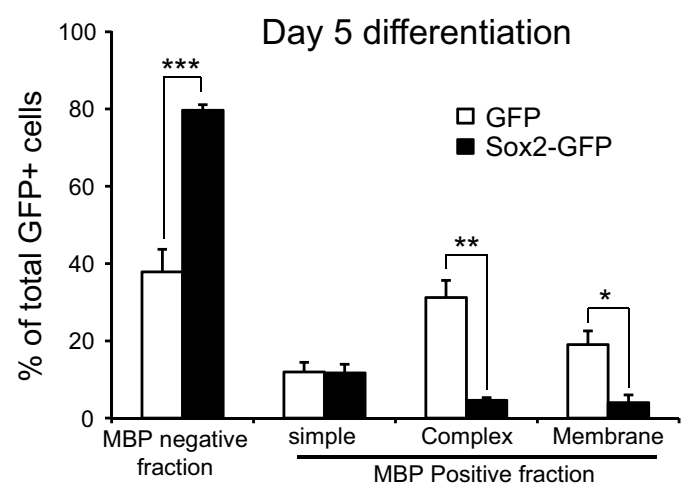

Figure 5. Effects of ablation and overexpression of Sox2 gene on OPCs in vitro. OPCs were isolated from neonatal Cag-creER:Sox ${ }^{f f f l}$ transgenic mice with non-Cre-expressing littermates as controls. A, Mice were injected with tamoxifen from P1 to P3 (blue arrows), and cell isolation was performed at P9. B, C, The reduction of Sox2 expression in OPCs was verified by immunocytochemistry, in which the nucleus localization of Sox2 (or the absence) in the area of dotted lines are illustrated in the insets. D-F, Comparison of Sox2 knock-out OPCs with controls at $4 \mathrm{~d}$ in vitro in the presence of mitogens PDGF-AA and NT-3. The Sox 2 knockout caused a decrease in total 0 lig $2^{+}$cells $(\boldsymbol{D})$, a reduction in Ki67 ${ }^{+}$proliferating cells $(\boldsymbol{E})$, and an increase in cell death, shown as pyknotic nuclei $(\boldsymbol{F})$. $\boldsymbol{G}$ shows reduced migration of Sox2-null OPCs examined immediately following isolation by transwell migration assay for $4 \mathrm{~h}$. $\boldsymbol{H}$, Under (Figure legend continues.) 
cells also expressed the proliferation marker Ki67 (Fig. 2K). These results indicated that Sox 2 is expressed by OPCs in response to focal acute demyelination.

\section{Sox 2 is expressed by OPCs in multiple sclerosis lesions}

To examine the expression of Sox 2 in clinical disease, we performed immunohistochemistry on postmortem MS brain tissue. In normal appearing white matter away from lesions, sparse, weakly stained Sox2-expressing cells were detected (Fig. 3B). At the periphery of active lesions, Sox ${ }^{+}$cells with stronger staining intensity were detected (Fig. 3D). Double-labeling immunohistochemistry revealed that Sox 2 colocalized with Olig2 in the nuclei, suggesting that Sox 2 expression occurred in oligodendrocyte lineage cells (Fig. 3E-H).

\section{Sox2-labeled OPCs are progeny of resting OPCs and a source} of remyelinating oligodendrocytes following demyelination

Since in the prelesion white matter Sox 2 is expressed by astrocytes and not by OPCs, the question arose of whether the Sox $2^{+}$cells present within the lesion after demyelination had arisen from prelesion Sox ${ }^{+}$astrocytes or as a result of increased expression in recruited (and for the most part newly generated) OPCs. We addressed this question using inducible Cre-lox reporter lines in which the reporter protein YFP is expressed in either PRGFRA ${ }^{+}$ OPCs (Pdgfra-creER ${ }^{T 2}$ :Rosa26-floxedSTOP-YFP; Zawadzka et al., $2010)$ or in $\mathrm{GFAP}^{+}$astrocytes (Gfap-creER ${ }^{T 2}$ :Rosa26-floxedSTOP-YFP; Hirrlinger et al., 2006). Expression of YFP in either OPCs or astrocytes within normal prelesion white matter was induced by systemic administration of tamoxifen $10 \mathrm{~d}$ before the focal demyelination was created by the injection of lysolecithin into spinal cord white matter (Fig. 4A). In the OPC-YFP mice, the $\mathrm{YFP}^{+}$cells did not express Sox 2 in unlesioned spinal cord white matter, but many Sox ${ }^{+}$cells were present within the demyelinated area at both 5 and $14 \mathrm{dpl}$, indicating increased expression of Sox2 in recruited OPCs that had either been labeled or were derived from cells labeled before lesion induction (Fig. 4C-E). In the astrocyte-YFP mice, many of the $\mathrm{GFAP}^{+}$astrocytes within the lesion expressed Sox2, but none of these cells expressed CC-1, a marker of differentiated oligodendrocytes (data not shown). In a separate experiment, we traced the progeny of Sox2-expressing cells following demyelination using Sox2creER ${ }^{T 2}$ :floxedSTOPRosa26-fGFP mice, where the recombination was induced immediately following demyelination (Fig. 4Ab). In an unlesioned spinal cord at $7 \mathrm{~d}$ after tamoxifen induction, substantial numbers of fGFP ${ }^{+}$cells were found. These cells did not express the OPC marker NG2 (Fig. 4E) or the oligodendrocyte lineage marker Olig2, which is consistent with our earlier observation that Sox 2 expression is minimal in nonactivated adult oligodendrocyte lineage cells. However, in demyelinated areas at $7 \mathrm{dpl}$, numerous fGFP ${ }^{+}$cells colabeled with NG2 and Olig2 (Fig. $4 F, G)$. The Sox2-labeled cells gave rise to $\mathrm{CC}-1^{+}$differentiated oligodendrocytes in the lesions at $14 \mathrm{dpl}$ (Fig. 4H). The majority

\section{$\leftarrow$}

(Figure legend continued.) proliferating culturing conditions, Sox2 ablation did not alter the proportion of MBP-expressing cells in the 0 lig2 ${ }^{+}$population. $\boldsymbol{I} \boldsymbol{K} \boldsymbol{K}$, Extent of differentiation of OPCs was assessed by calculating the proportions of three levels of morphological complexity of MBP-expressing cells ( $\boldsymbol{I}$ ) following the withdrawal of PDGF-AA and NT-3, and the addition of T3 at day $3(\boldsymbol{J})$ and day $5(\boldsymbol{K})$, respectively. $L-N, 0$ verexpression of $S 0 \times 2$ by transfecting isolated rat $O P C s$ resulted in a decreased number of MBP-expressing cells $(\boldsymbol{L}, \boldsymbol{M})$ and was quantified by the relative number of levels of morphological complexity of MBP labeling $(N)$. All values are the mean \pm SE. $n=3 .{ }^{* *} p<0.01,{ }^{* * *} p<0.001$, unpaired $t$ tests comparing knockouts and controls. Scale bars: (in $B) B, C, 100 \mu \mathrm{m} ; I, 50 \mu \mathrm{m}$; (in $L) L, M, 50 \mu \mathrm{m}$. of $\mathrm{GFAP}^{+}$astrocytes in the lesion were also $\mathrm{fGFP}^{+}$(Fig. 3I). These data indicate that the resting OPCs in CNS white matter respond to demyelination by expressing Sox 2 and subsequently differentiate into remyelinating oligodendrocytes.

\section{Decreased expression of Sox 2 is necessary for oligodendrocyte differentiation}

We have shown that during developmental myelination Sox2 expression is reduced in the later stages of the oligodendrocyte lineage associated with myelination (Fig. $1 D-F, H$ ). We next asked whether decreased expression of Sox 2 was also associated with OPC differentiation into remyelinating oligodendrocytes. In the rat CCP-EB model, little Sox2 expression was detected at $21 \mathrm{dpl}$ (when remyelination is complete) in oligodendrocytes expressing any of the oligodendrocyte markers CC-1, transferrin, and PLP mRNA (Fig. $2 L, M, P$ ); neither did we see Sox2 expression in periaxin-expressing remyelinating Schwann cells, many of which we have previously shown are of OPC origin (Zawadzka et al., 2010; Fig. 2Q). Sox2 was expressed only in cells with nuclear Olig1 expression (occurring in OPCs at an earlier stage of remyelination), but not in cells with cytoplasmic Olig1 expression (occurring in mature oligodendrocytes in later stages of the lineage; Arnett et al., 2004; Kitada and Rowitch, 2006; Niu et al., 2012; Fig. 2N,O). These observations suggest that downregulation of Sox 2 may be required for OPC differentiation. To test whether the presence of Sox 2 is sufficient to inhibit OPC differentiation, we transfected cultured rat OPCs with a full-length Sox2 sequence under the control of the CMV promoter and found that overexpression of Sox 2 in OPCs resulted in a significant reduction in differentiation, which was revealed by both a decrease in the proportion of Olig2 ${ }^{+}$cells that expressed MBP and the presence of fewer cells with the complex morphology of differentiated cells (Fig. $5 L-N$ ). This result indicates that Sox2 is an intrinsic differentiation inhibitor, along with several other transcription factors such as hes5 (Kondo and Raff, 2000; John et al., 2002; Liu et al., 2006; Zhang et al., 2009), id2/4 (Kondo and Raff, 2000; Chen et al., 2012), and Tcf7l2 (Fu et al., 2009; Fancy et al., 2008).

\section{Loss of Sox 2 reduces OPC proliferation and survival in vitro}

A role for Sox 2 in inhibiting OPC differentiation predicts that the loss of Sox 2 will lead to premature differentiation, and accelerated myelination and remyelination. We tested this prediction using a double-transgenic mouse line expressing tamoxifeninducible CAG promoter (chicken $\beta$-actin promoter with CMV enhancer), and controlled Cre recombinase and Sox2 gene flanked by loxP sites (CAG-creER:Sox $\left.2^{f l / f l}\right)$. Recombination was induced before OPC isolation by immunopanning with CD140a (PDGFRA) antibody, which resulted in efficient recombination of Sox 2 genes in all cells in the cre carriers and significant loss of Sox 2 protein in isolated OPCs, as revealed by immunostaining (Fig. $5 B, C$ ) and Western blotting (data not shown). OPCs from both Sox2-depleted mice and controls (non-Cre-expressing littermates) were grown for $4 \mathrm{~d}$ in the presence of the OPC mitogens PDGF-AA and NT3. Despite being seeded at the same density, there were $\sim 50 \%$ fewer Olig $2^{+}$cells in the Sox 2 -deficient cultures compared with controls (Fig. 5D). This difference was mirrored by a lower proportion of cells expressing the proliferation marker Ki67 and increased numbers of cells with pyknotic nuclei, which are indicative of cell death (Fig. $5 E, F$ ). In a transwell migration assay, involving plating freshly isolated OPCs into the top chamber of a $6 \mathrm{~mm}$ hanging cell culture insert (polyethylene terephthalate, $8 \mu \mathrm{m}$ pore size), there was a significant reduction 

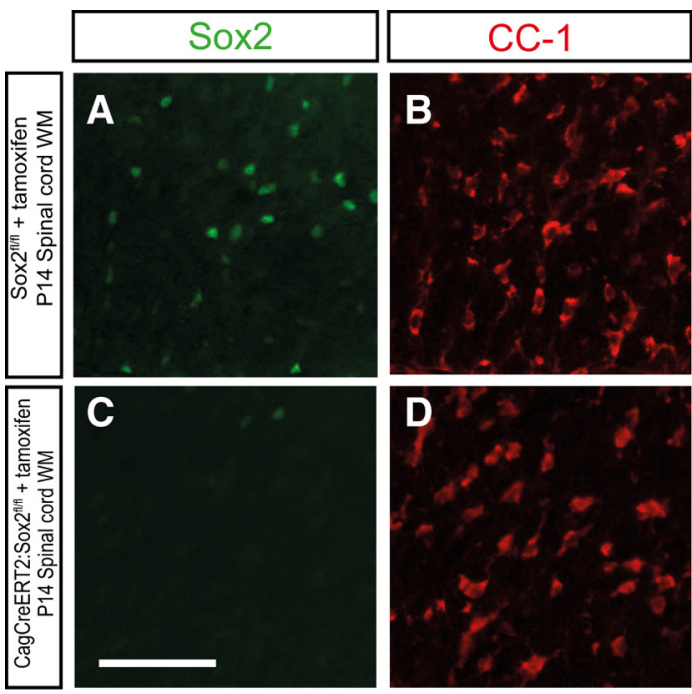

I

Sox2

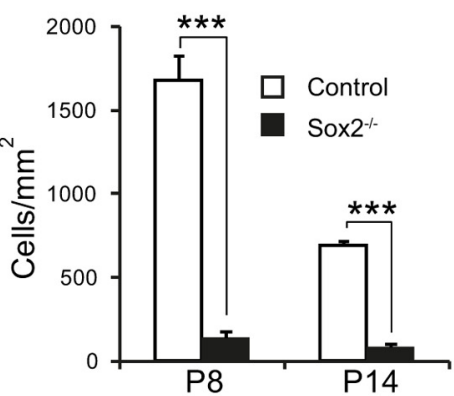

$\mathbf{L}$
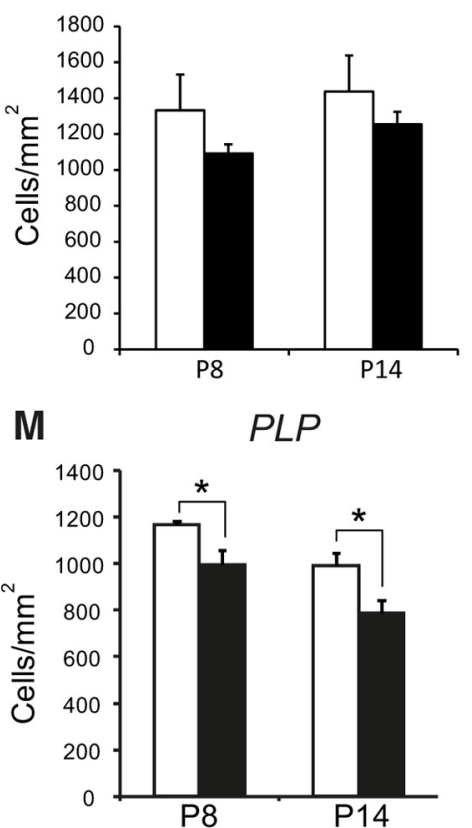

J
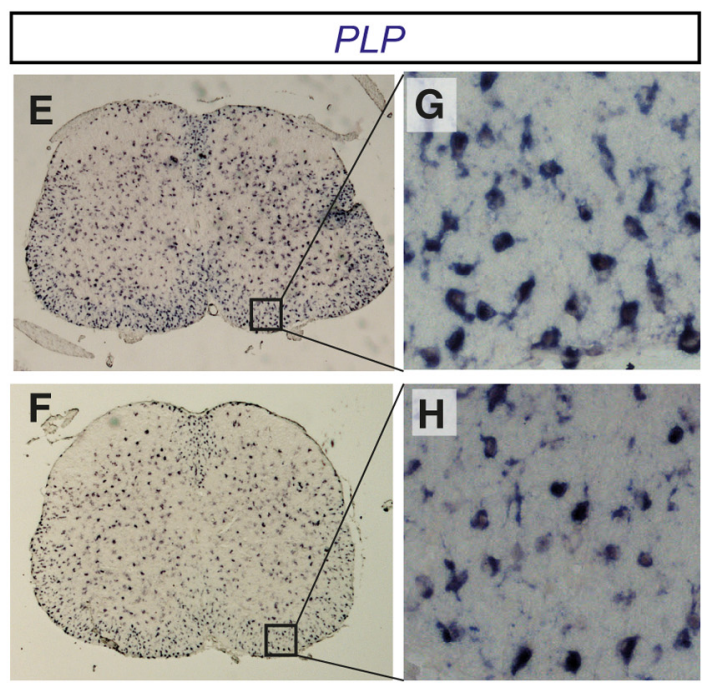

Olig2

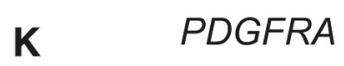

K
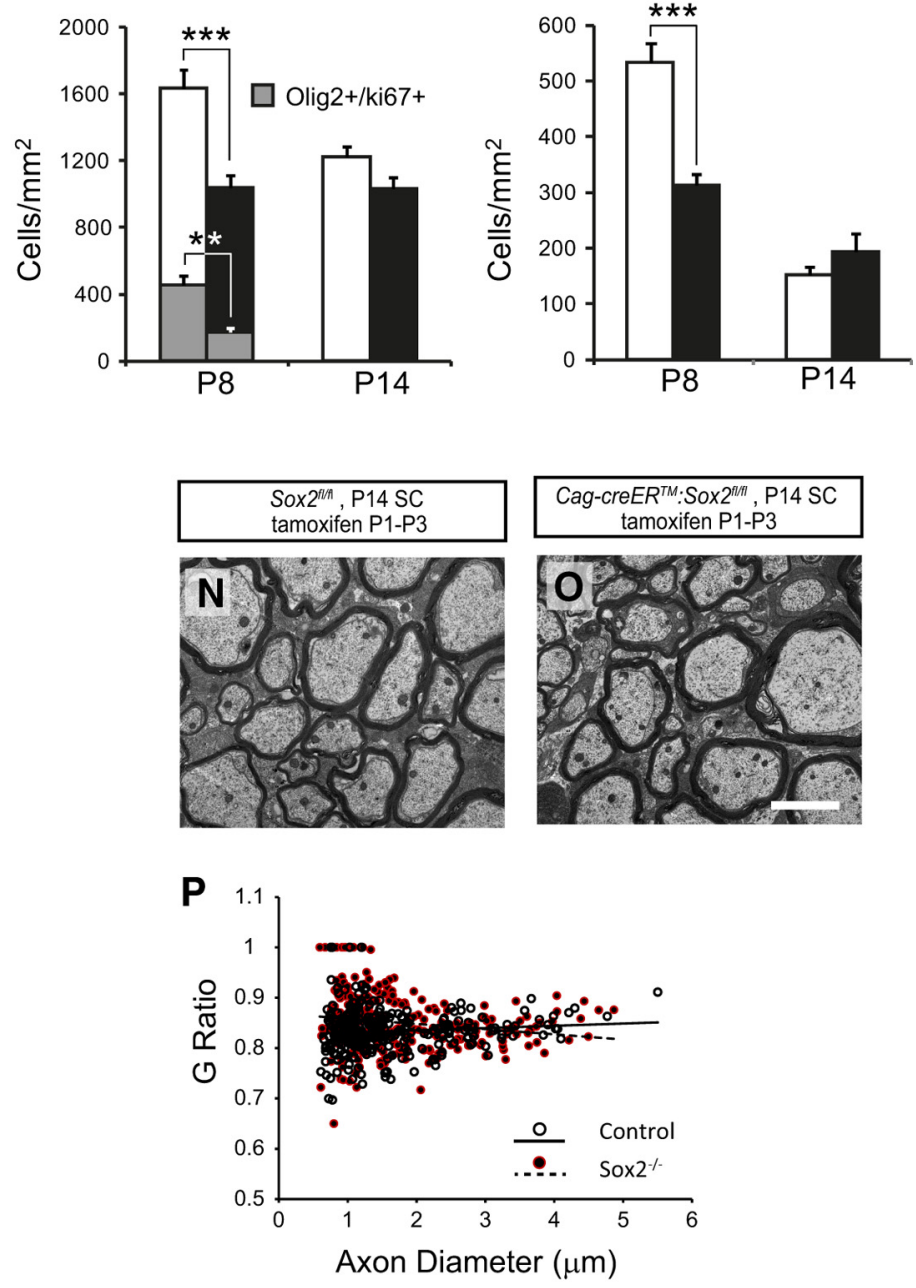

Figure 6. Deletion of Sox2 postnatally reduced numbers of OPCs but caused no impairment in developmental myelination. Mice expressing Cag-CreER:Sox $2^{f / / f l}$ and control Sox $2^{f l / f l}$ littermates received tamoxifen from $P 1$ to $P 3$, and were analyzed at the indicated time points. $\boldsymbol{A}-\boldsymbol{D}, \boldsymbol{I}, \boldsymbol{L}$, There was a loss of Sox2 expression in spinal cords of (re-expressing animals $(\boldsymbol{A}, \boldsymbol{C}$, and $\boldsymbol{I})$, but the densities of CC $-1^{+}$cells were similar $(\boldsymbol{B}, \boldsymbol{D}$, and $\boldsymbol{L})$. $\boldsymbol{J}$, 0 lig2 ${ }^{+}$cells were significantly decreased at P8 in knock-out animals, and this is mirrored by a decreased density of PDGFRA ${ }^{+}$cells and a reduction in $\mathrm{Ki}^{+} 7^{+}$proliferating 0 lig2 ${ }^{+}$cells (gray bars). $\boldsymbol{E}-\boldsymbol{H}, \boldsymbol{M}, \mathrm{A}$ mild $(<20 \%)$ but significant decrease in the numbers of PLP mRNA-expressing cells at both P8 and P14 was observed. $\mathbf{G}$ and $\boldsymbol{H}$ are enlarged boxed areas in $\boldsymbol{E}$ and $\boldsymbol{F}$, respectively. $\boldsymbol{N}-\boldsymbol{P}$, At P14, no visible difference was observed in myelin morphology in ventral spinal cord under electron microscopy ( $\boldsymbol{N}$, $\mathbf{0}$ ), which is confirmed by quantification of the g-ratio (P). Values are the mean \pm SE. $n=4 .{ }^{*} p<0.05,{ }^{* *} p<0.01,{ }^{* * *} p<0.001$, unpaired $t$ test. The legend in $\boldsymbol{I}$ also applies to $\boldsymbol{J}-\boldsymbol{M}$. Scale bars: (in $\boldsymbol{C}$ ) $\boldsymbol{A}-\boldsymbol{D}, 100 \mu \mathrm{m}$; $\boldsymbol{E}$, $\boldsymbol{F}, 1500 \mu \mathrm{m} ; \boldsymbol{G}, \boldsymbol{H}, 60 \mu \mathrm{m} ; \boldsymbol{N}, \mathbf{0}, 2.5 \mu \mathrm{m}$. 
A
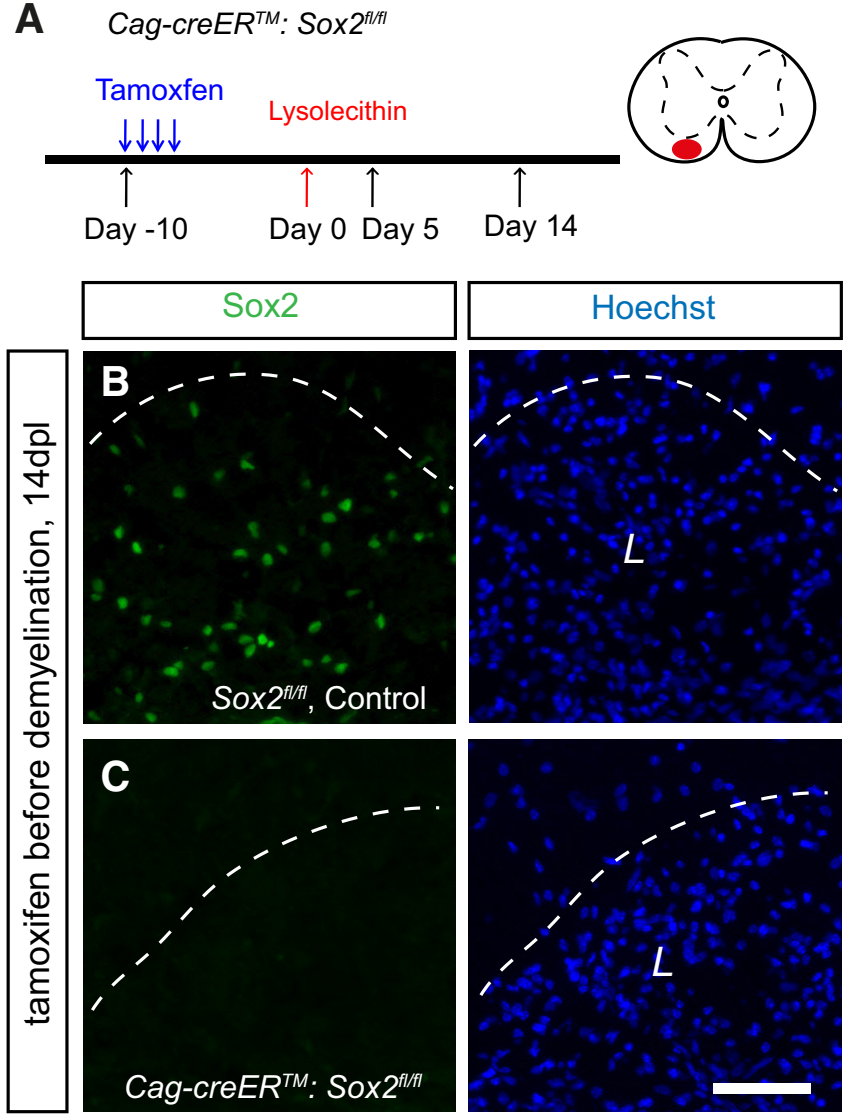

D

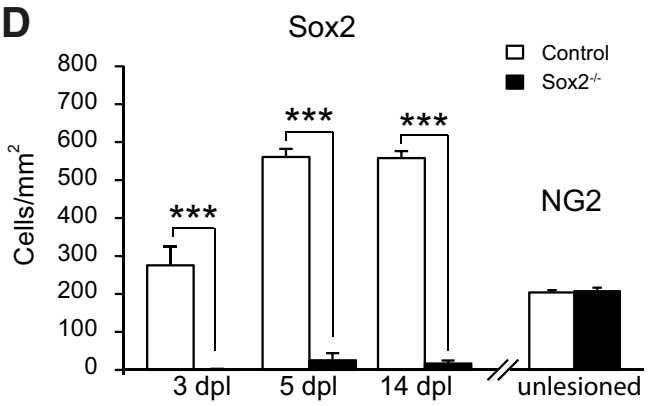

E

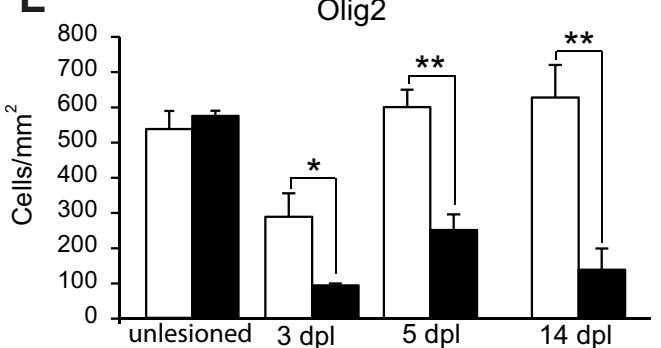

J

PLP
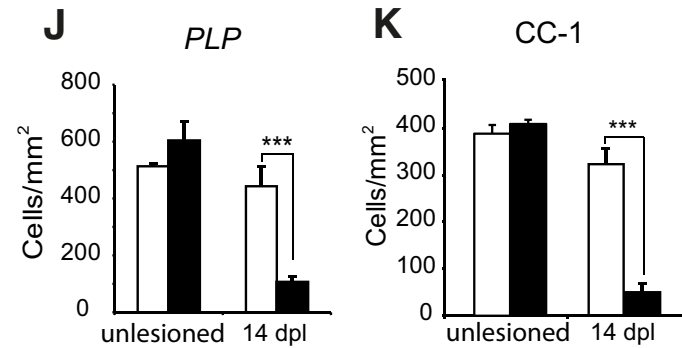
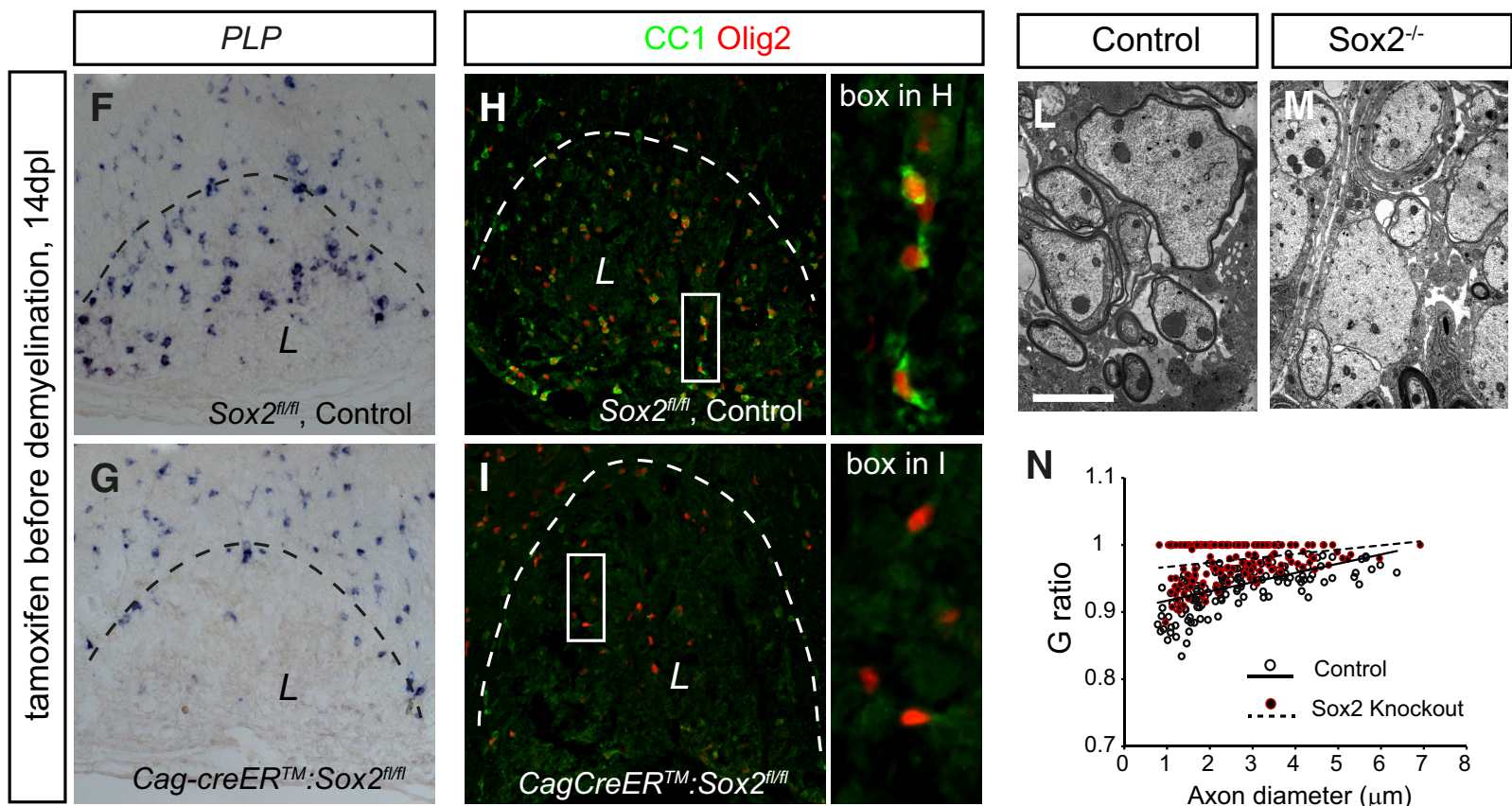

Figure 7. Ablation of the Sox2 gene before demyelination reduces the progenitor response to demyelination and impairs remyelination. $\boldsymbol{A}$, Timeline for the induction of Sox2 gene knockout and spinal cord demyelination in Cag-creESR $^{1}$ :Sox ${ }^{f / f l}$ mice. Efficient ablation of Sox2 expression is depicted in the image pairs in $\boldsymbol{B}$ and $\boldsymbol{C}$ as examples of lesion areas at 14 dpl; quantification is shown in $\boldsymbol{D}$. $\boldsymbol{E}-\boldsymbol{K}$, There was a significant reduction in the number of oligodendrocyte lineage marker 0 lig $2^{+}$cells in demyelinated areas throughout the remyelination process ( $\left.\boldsymbol{E}-\boldsymbol{G}\right)$, and a significant reduction in the number of cells labeled with mature oligodendrocyte markers C(-1 and PLP mRNA (images, $\boldsymbol{F}-\boldsymbol{I}$; graphs, $\boldsymbol{J}, \boldsymbol{K}$ ) at $14 \mathrm{dpl}$ in Sox 2 knock-out animals compared with non-Cre-expressing littermates. The dotted lines in the images delineate the boundary of the lesioned area (marked by $\boldsymbol{L}$ ). $\boldsymbol{K}-\boldsymbol{N}$, The decreased expression of the differentiation markers was mirrored by poorer remyelination under electron microscopy $(\boldsymbol{L}, \boldsymbol{M})$, and g-ratio analysis $(\boldsymbol{N})$. Values are the mean \pm SE. $n=4-6 .{ }^{* *} p<0.01,{ }^{* * *} p<0.001$, nonpaired $t$ tests. Legends in $\boldsymbol{D}$ apply to all graphs except for $\boldsymbol{N}$. Scale bars: $\boldsymbol{B}, \boldsymbol{C}, 50 \mu \mathrm{m} ; \boldsymbol{F}-\mathbf{I}, 100 \mu \mathrm{m} ; \boldsymbol{L}, 2.5 \mu \mathrm{m}$. 

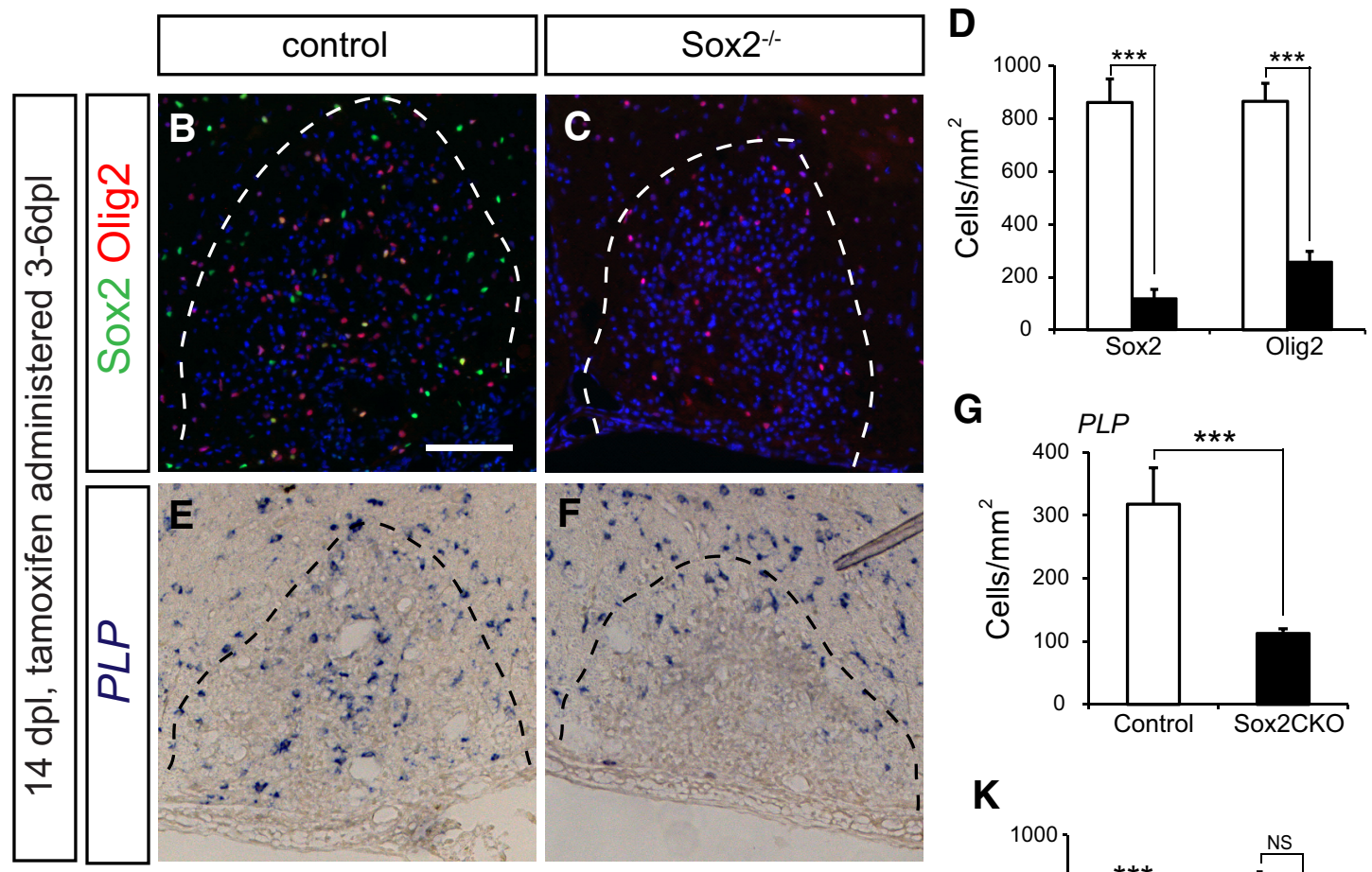

G
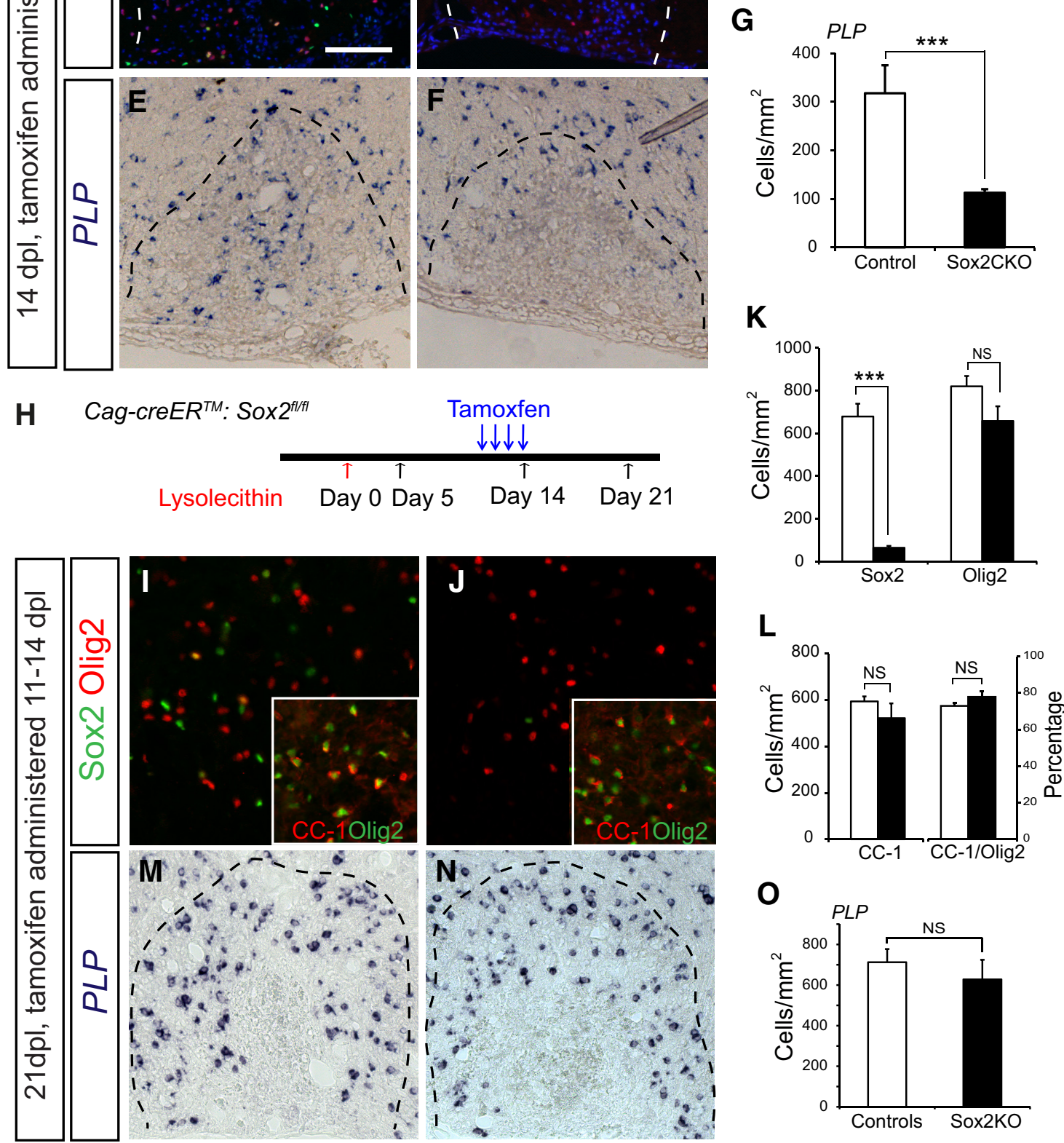

Figure 8. Impairment of remyelination occurs when Sox2 is removed at the recruitment stage of remyelination. $\boldsymbol{A}, \boldsymbol{H}$, Mice at 8 -9 weeks of age carrying Cag-creER:Sox $2^{f / f l}$ genes or Sox $2^{f / f l}$ (Control) were injected for early tamoxifen induction $(\boldsymbol{A})$ and for Sox2 knockout at 3-6 dpl, and were examined at $14 \mathrm{dpl}$, or they were injected for late tamoxifen induction $(\boldsymbol{H})$ at $11-14 \mathrm{dpl}$ and examined at $21 \mathrm{dpl}$. $\boldsymbol{B}-\mathbf{G}, \boldsymbol{I}-\mathbf{N}$, Early induction led to a severe reduction in the density of 0 lig $2^{+}$cells $(\boldsymbol{B}-\boldsymbol{D})$ and a decrease in the numbers of PLP $\mathrm{mRNA}{ }^{+}$oligodendrocytes in the lesion $(\boldsymbol{E}-\boldsymbol{G})$. Late

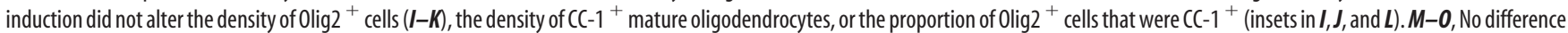
was found in the densities of PLP mRNA ${ }^{+}$oligodendrocytes in the lesions following late tamoxifen induction. The dotted lines in the images delineate the boundary of the lesioned area. Data are shown as the mean \pm SE. $n=4-6$. NS, Not significant. ${ }^{* * *} p<0.001$, nonpaired $t$ test. Scale bars: (in $\left.\boldsymbol{B}\right) \boldsymbol{B}, \boldsymbol{C}, \boldsymbol{E}, \boldsymbol{F}, 100 \mu \mathrm{m}$; (in $\left.\boldsymbol{M}\right) \boldsymbol{M}, \boldsymbol{I}, \boldsymbol{J}, \boldsymbol{L}, 50 \mu \mathrm{m}$. 

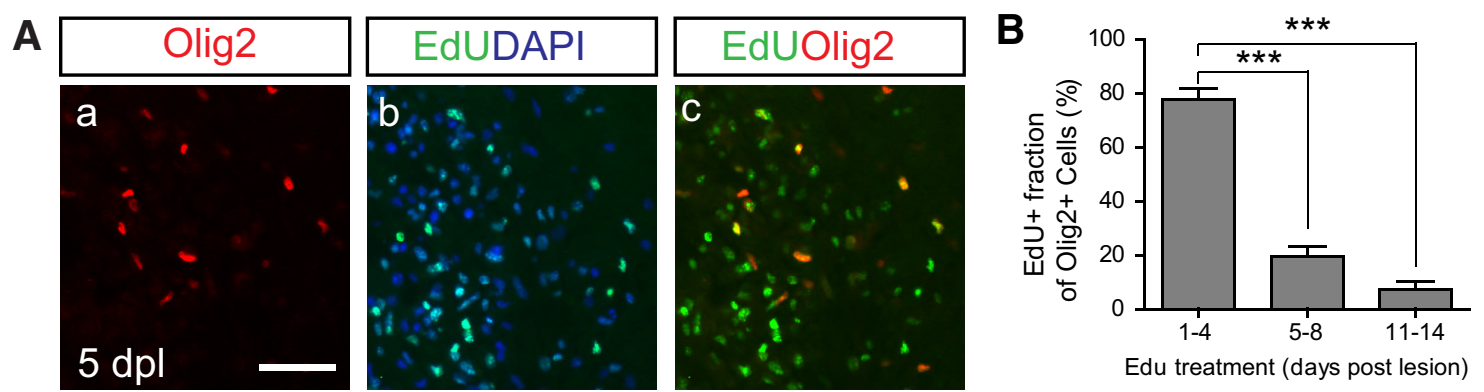

Figure 9. Proliferation of OPCs occurs predominantly in the first week during remyelination. Mice received EdU in their drinking water for different periods following demyelination. $A$, illustrates a demyelinated area at $5 \mathrm{dpl}$ labeled for 0 lig2 and EdU. B, 0 lig $2^{+}$cells incorporating EdU were quantified as a proportion of 0 lig2 ${ }^{+}$cells at $5 \mathrm{dpl}$ (for mice receiving EdU at $1-4 \mathrm{dpl}$ ) and $14 \mathrm{dpl}$ (for mice receiving EdU at $5-8$ or $11-14 \mathrm{dpl}$ ). Data are the mean \pm SE. $n=4-5$. ${ }^{* * *} p<0.001$. Scale bar, $50 \mu \mathrm{m}$.

in the number of OPCs migrating to the underside within a $4 \mathrm{~h}$ period across the gradient of mitogens, suggesting impaired OPC migration in the absence of Sox2 (Fig. 5G). Despite the presence of OPC mitogens, a proportion of OPCs differentiated into Olig ${ }^{+} / \mathrm{MBP}^{+}$cells; however, the proportion of these cells among the Olig2 population was the same in both groups (Fig. $5 H)$. Under differentiating conditions, which were created by the withdrawal of mitogens and the addition of thyroid hormone (T3) for 3 or $5 \mathrm{~d}$, there was an impaired differentiation in the Sox2-deficient cells compared with controls, which was revealed as a decrease in the proportion of $\mathrm{MBP}^{+}$cells with mature membrane-bearing morphology (Fig. $5 I-K$ ). This result was at variance with our hypothesis that the absence of Sox 2 would accelerate differentiation. A possible explanation is that the extent of differentiation was the consequence of reduced numbers of cells in Sox2-deficient cultures, as the rate of differentiation is closely associated with OPC densities (Yang et al., 2005, Rosenberg et al., 2008). However, a recent report (Hoffmann et al., 2014) has shown that Sox 2 expression is retained at the early stage of terminal differentiation and is important for differentiation. Although obtained using OPCs from neonatal CNS that may not necessarily predict the behavior of adult-derived OPCs, our in vitro data suggest that Sox 2 is a positive contributor to OPC proliferation and survival, and that its expression is also required to "prime" OPCs for full differentiation.

\footnotetext{
Ablation of Sox 2 in vivo has a minor effect on developmental myelination but impairs OPC recruitment and remyelination after demyelination

We next tested the effect of Sox2 knockout on developmental CNS myelination and remyelination in vivo using a highly efficient Sox 2 knock-out line, Cag-creER:Sox $2^{f l f l}$. Postnatal administration of tamoxifen at $\mathrm{P} 1-\mathrm{P} 3$ resulted in a nearly complete loss of Sox ${ }^{+}$cells throughout the spinal cord when examined at P8 and $\mathrm{P} 14$ (Fig. $6 A, C, I$ ). This led to a $40 \%$ reduction in density of PDGFRA mRNA ${ }^{+}$OPCs and Olig ${ }^{+}$oligodendrocyte lineage cells, and a reduction in $\mathrm{Ki}_{6}{ }^{+}$proliferating Olig2 ${ }^{+}$cells at P8 (Fig. 6J,K). However, at P14 there was only a modest reduction in PLP mRNA-expressing cells but no significant difference in the densities of either Olig $2^{+}$and $\mathrm{CC}-1^{+}$cells (Fig. $6 L, M$ ). No difference was detected in myelination examined by electron microscopy, and similar g-ratios were obtained in ventral spinal cord white matter obtained from control and Sox2 knock-out littermates (Fig. $6 N-P$ ). These data indicate that deletion of the Sox2 gene at an early postnatal stage transiently reduces the number of proliferating OPCs but has no sustained effect on myelination. The absence of Sox 2 knockout in vivo did not result in precocious OPC differentiation.
}

Demyelination was induced in ventral spinal cord white matter 10-12 d after tamoxifen administration in Cag-creER:Sox $2^{f l f l}$ and control mice. As in development, recombination resulted in a reduction in Sox 2 expression throughout the spinal cord, including the area of demyelination (see Fig. $7 B-D$ ). The loss of Sox 2 did not alter the densities of oligodendrocyte lineage cells in unlesioned spinal cord white matter, but resulted in a reduction of Olig $2^{+}$cells in the lesion area compared with controls at 3, 5, and $14 \mathrm{dpl}$, supporting a role for Sox 2 in OPC recruitment following demyelination (Fig. $7 D, E$ ). Compared with controls, there was a substantial reduction in $\mathrm{CC}-1^{+}$and PLP mRNAexpressing cells within lesions in Sox2-deficient animals (Fig. $7 F, G, J, K)$, which was reflected in reduced remyelination and higher g-ratios (indicative of thinner myelin sheaths; Fig. $7 L-N$ ).

The data from Sox 2 knock-out mice indicated a role for Sox 2 in the repopulation of demyelinated areas by OPCs and in subsequent impairment in remyelination. A possible explanation for the impaired remyelination is that it occurs as a consequence of the reduced recruitment rather than being due to the role of Sox2 in OPC differentiation per se. We therefore reasoned that if Sox2 impaired remyelination due to its effects on OPC recruitment, then ablation of Sox 2 during the recruitment phase of remyelination would impair remyelination, while ablation during the differentiation phase would not. To test this, we induced Sox2 knockout at 3-6 dpl (OPC recruitment phase) or 11-14 dpl (differentiation phase) in Cag-creER:Sox $2^{f l / f l}$ mice. Tamoxifen injection at both stages resulted in a substantial loss of Sox 2 in lesions (Fig. $8 B-D, I-K)$. However, only in the early knockout was there a significant reduction of differentiated oligodendrocytes in lesions (Fig. $8 E-G, L-N$ ). We next demonstrated by EdU incorporation that, following demyelination, OPC proliferation predominantly occurs in the first $5 \mathrm{dpl}$, though small numbers continue to proliferate at $14 \mathrm{dpl}$ (Fig. 9). From this, we inferred that Sox2 plays a role in the OPC recruitment stage of CNS remyelination.

\section{Impairment of remyelination is primarily attributable to loss of Sox 2 in OPCs}

Since Sox 2 is expressed by both astrocytes and OPCs following demyelination, the impaired remyelination in Cag-creER:Sox $2^{\text {flf } f l}$ mice, in which the Sox 2 gene is deleted in all cell types, could be, at least in part, the consequence of a loss of Sox 2 in astrocytes, which are known to play important roles in oligodendrocyte remyelination (Franklin et al., 1991, 1993; Talbott et al., 2005). We therefore next tested the effect of Sox2 knockout specifically within oligodendrocyte lineage cells. In initial experiments, we used an OPC-specific inducible Sox2 knock-out line (Pdgfra$\left.\operatorname{creER} R^{T 2}: S o x 2^{f l / f l}\right)$. However, the efficiency of recombination in 
A

Sox10-icreER $R^{T 2}:$ Sox $2^{\text {fift }}$
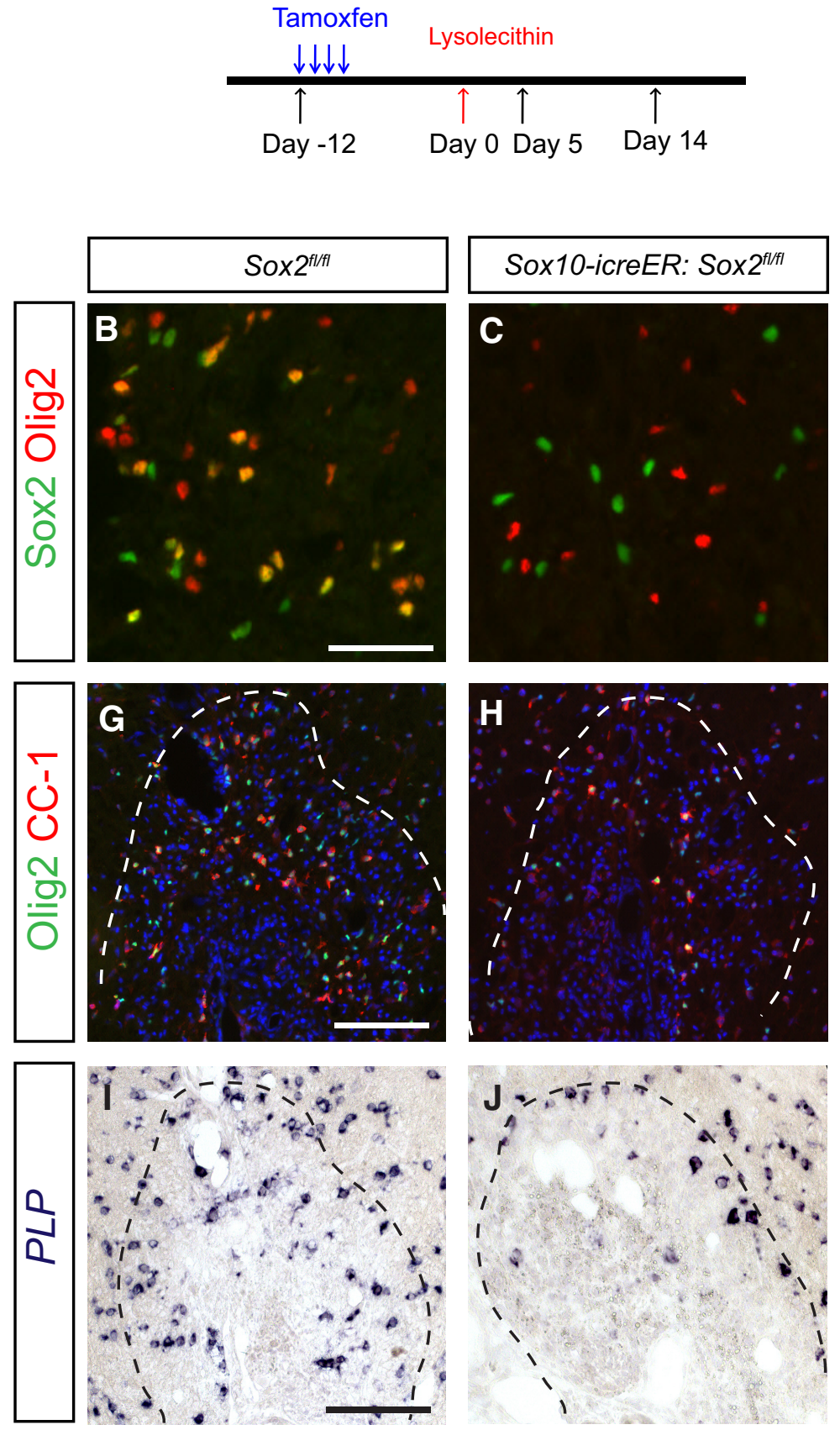
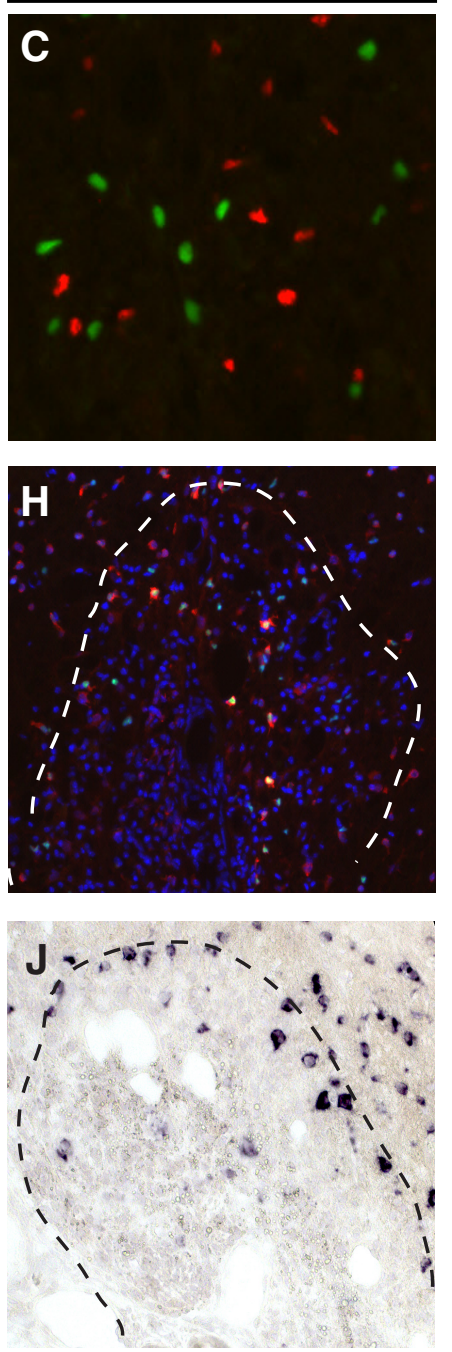

Control

D
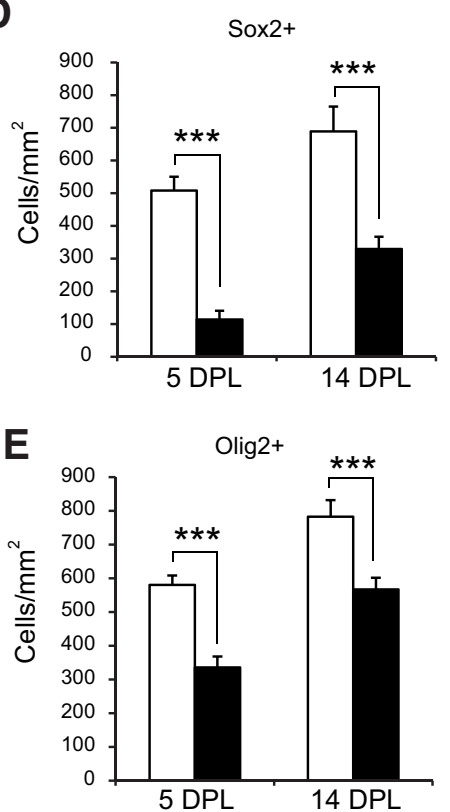

F

Sox2+Olig2+
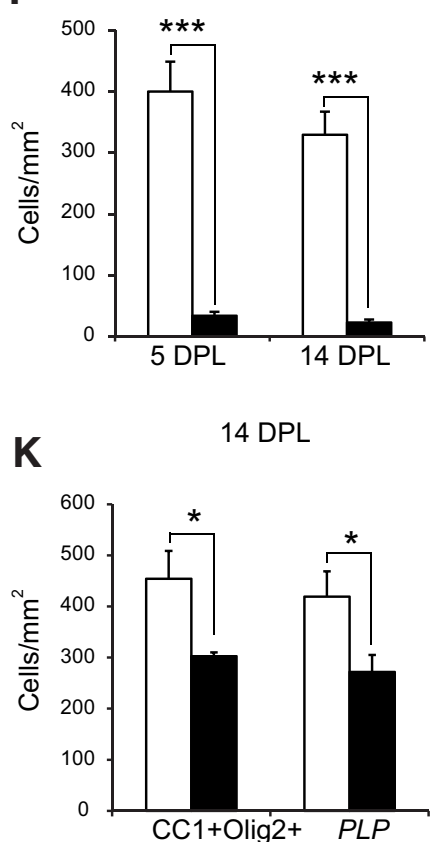

Figure 10. Impairment of remyelination following the ablation of Sox2 is attributed to its direct effects on OPCs. A, Oligodendrocyte lineage-specific knockout of Sox2 was induced in Sox10-icreER $R^{T 2}$ :Sox ${ }^{f / f f}$ (Sox2CKO) mice from $12 \mathrm{~d}$ before demyelination in spinal cord. $\boldsymbol{B}-\boldsymbol{D}, \boldsymbol{F}$, Double-labeling immunofluorescence in the demyelinated areas shows clear reduction of Sox2 ${ }^{+}$cells and almost an absence of Sox $2^{+}$Olig2 ${ }^{+}$cells in Sox2CKO animals $(\boldsymbol{C})$ compared with controls $(\boldsymbol{B}$, quantification in $\boldsymbol{D}$ and $\boldsymbol{F}$ ) at both 5 and $14 \mathrm{dpl}$. $\boldsymbol{B}, \boldsymbol{C}, \boldsymbol{E}$, There is a significant reduction of oligodendrocyte lineage cells labeled by 0 lig2 at both 5 and $14 \mathrm{dpl}$. $\mathbf{G}-\mathbf{J}$, In demyelinated areas, the numbers of mature oligodendrocytes labeled by $\mathrm{CC}-1$ immunostaining $(\mathbf{G}, \boldsymbol{H})$ and PLP mRNA in situ hybridization $(I, J)$ are also decreased in Sox2CKO animals compared with the control group (quantification shown in $\boldsymbol{K}$ ). Data are shown as mean \pm SE. $n=5 .{ }^{*} p<0.05,{ }^{* * *} p<0.001$. Scale bars: (in $\boldsymbol{B}) \boldsymbol{B}, \boldsymbol{C}, 50 \mu \mathrm{m}$; (in $\boldsymbol{C}) \boldsymbol{C}, \boldsymbol{G}, \boldsymbol{H}, 100 \mu \mathrm{m}$; (in $\boldsymbol{I}) \boldsymbol{I}, \boldsymbol{J}, 100 \mu \mathrm{m}$.

these mice was low, and the data generated were inconclusive (data not shown). We therefore performed subsequent experiments using an oligodendrocyte lineage-specific knock-out line, Sox $10-i c r e E R^{T 2}:$ Sox $2^{f l / f l}$, which produced a $>90 \%$ reduction in the numbers of Sox $2^{+}$Olig2 ${ }^{+}$cells (Fig. 10C,F) in lesions. Using this line, we were able to replicate the remyelination phenotype of constitutive inducible knockout in Cag-creER:Sox $2^{\text {flffl }}$, although to a smaller extent (Fig. 10). Sox2 knockout did not lead to mor- phological changes in $\mathrm{GFAP}^{+}$astrocytes in white matter at the developmental and adult stages (Fig. 11B-E). Following toxininduced demyelination, there were no obvious differences in the $\mathrm{GFAP}^{+}$astrocytes (Fig. $11 F, G$ ), although this does not preclude functional changes that are not evident by GFAP immunostaining. In subsequent experiments using a tamoxifen-inducible astrocyte conditional Sox2 knockout $\left(G F A P-\operatorname{cre} E R^{T 2}: S o x 2^{f l / f l}\right)$, we did not detect a significant difference in astrocyte Sox 2 knockout 
A Myelination

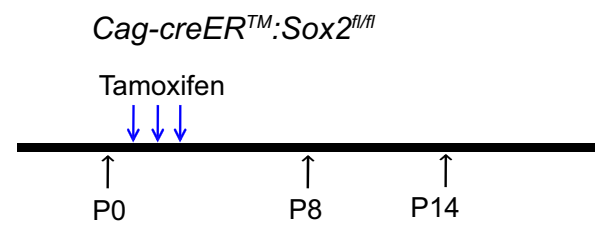

\section{Remyelination}

Cag-creER ${ }^{T M}:$ Sox $2^{\text {f/fl }}$ or Gfap-creER ${ }^{T 2}:$ Sox $2^{\text {fffl }}$

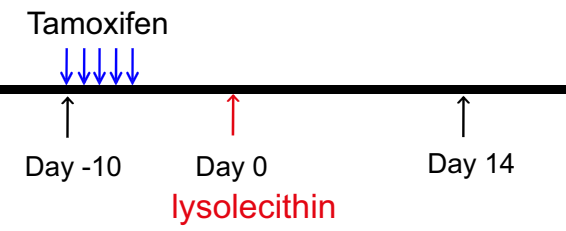

\section{H Demyelination at $14 \mathrm{dpl}$}

$h G F A P-c r e E R^{T 2}: S o x 2^{\text {ffft }}$

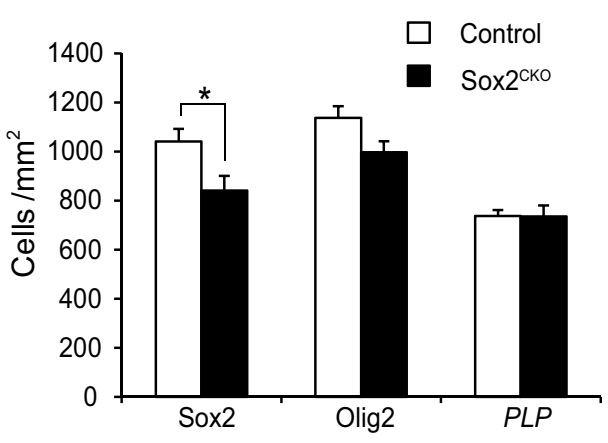

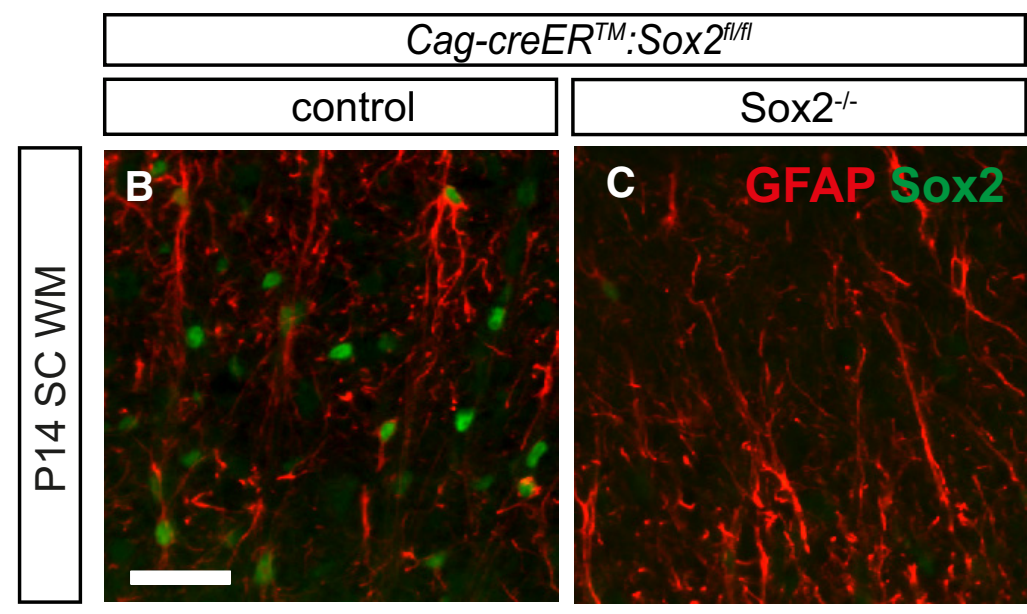
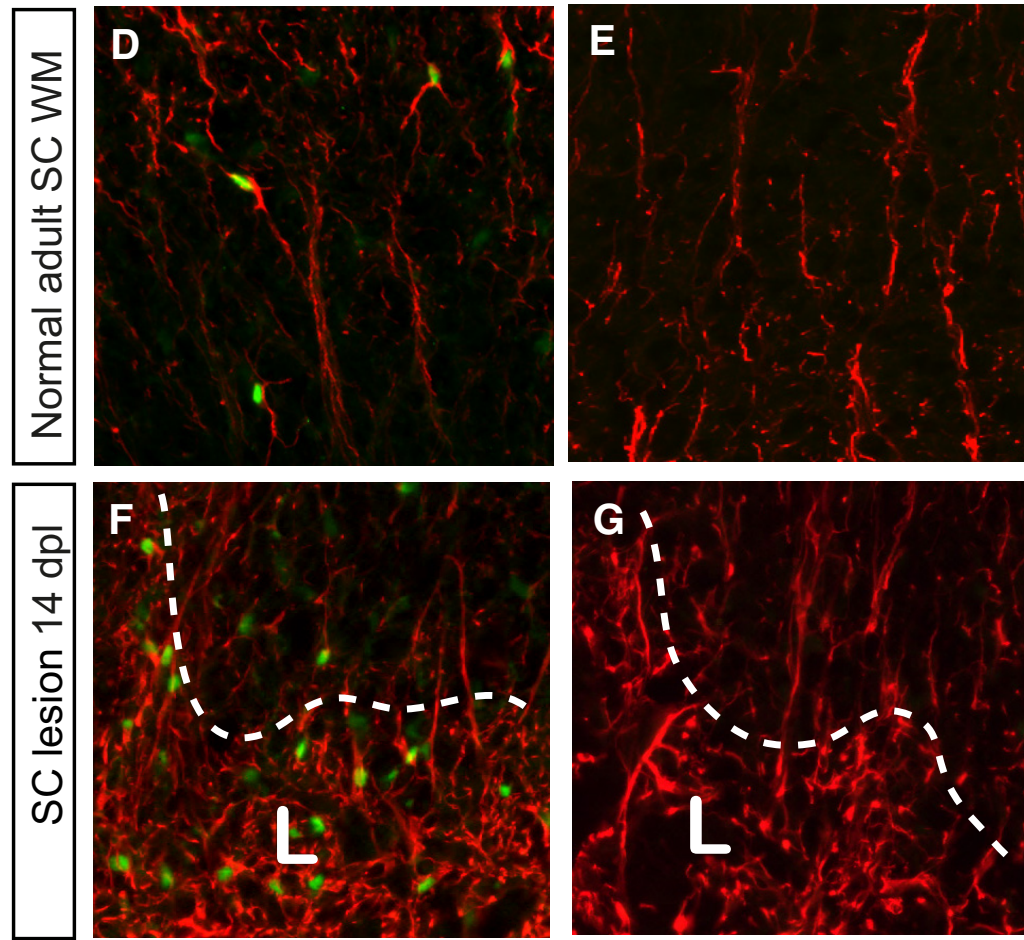

Figure 11. Astrocytes develop normally and respond similarly to demyelination in Sox2 knock-out mice. Tamoxifen induction in neonate and adult mice was performed according to protocols illustrated in $\boldsymbol{A}$. $\boldsymbol{B}-\boldsymbol{G}$, Images show transverse sections of ventral spinal cord (SC) white matter (WM) from unlesioned mice and from lesions in $14 \mathrm{dpl}$ controls $(\boldsymbol{B}, \boldsymbol{D}, \boldsymbol{F})$ and Cag-creER:Sox $2^{f / f f l}$ mice treated with tamoxifen with respective protocols $(\boldsymbol{C}, \boldsymbol{E}, \boldsymbol{G})$. Double-labeling immunofluorescence for Sox2 and GFAP show a nearly complete loss of Sox2 in knock-out animals in both development (tamoxifen administered at $P 1-P 3 ; \boldsymbol{C}$ ) and adulthood $(\sim P 60 ; \boldsymbol{E}, \boldsymbol{G}) . \boldsymbol{H}$, quantitative analyses of remyelination in the mouse line with astrocyte conditional Sox2 knockout $\left(G F A P-c r e E R^{T 2}\right.$ :Sox2 $\left.2^{f f f}\right)$. The lesion areas were marked with "L," and the approximate border is drawn with a dotted line. Data are the mean \pm SE. $n=4 .{ }^{*} p<0.05$, unpaired Student's $t$ test. Scale bar: (in $\boldsymbol{B}$ ) $\boldsymbol{B}-\mathbf{G}, 50 \mu \mathrm{m}$.

from control mice in remyelination (Fig. 11H). This finding supports the interpretation that impaired remyelination in lysolecithin-injected mice is primarily due Sox 2 ablation in OPCs.

\section{Discussion}

The two keys steps in remyelination are as follows: first, the recruitment of OPCs to and their expansion within areas of demyelination; and, second, the differentiation of recruited cells into new postmitotic myelin-forming oligodendrocytes. The recruitment stage occurs rapidly following acute demyelination and is necessary to provide sufficient numbers of cells that are capable of remyelinating the entire area of demyelination. This usually involves generating a superfluity of cells, such that the number generated is in excess of the number required (a common pattern in both developmental and re- generative biology). The differentiation phase requires OPCs to drop out of the cell cycle and initiate a myelination program that reinvests the demyelinated axon with new myelin sheaths. During the recruitment phase, it is essential that cells do not differentiate prematurely, potentially leading to a shortfall in the number required to make a sufficient number of oligodendrocytes. The control of these two stages of remyelination involves a network of transcription factors, whose pattern of expression carefully regulates the timely transition from one phase to another (Sohn et al., 2006; Magri et al., 2014). For example, tcf7l2, hes5, and id $2 / 4$ are transcription factors whose expression increases the number of OPCs following demyelination as part of the OPC activation response, and inhibiting oligodendrocyte differentiation (Fancy et al., 2008). At a critical stage, the expression of these transcription factors 
needs to be suppressed in order for differentiation to occur. Chromatin modification through histone acetylation by histone deacetylases is a key mechanism involved in the suppression of differentiation inhibitory transcription factors (Liu and Casaccia, 2010). Dysregulation of these mechanisms can alter the kinetics of remyelination, causing it to occur slowly, as it occurs in aging (Shen et al., 2008).

In this study, we show that the transcription factor Sox 2 has a distinctive pattern of expression during myelination and remyelination. In developmental myelination, Sox2 is expressed in OPCs, but is no longer expressed as these cells differentiate into myelinating oligodendrocytes or persist as adult OPCs. Thus, in the adult it ceases to be detectable in oligodendrocyte lineage cells and can only be detected in a subset of astrocytes. However, following acute demyelination, Sox 2 is expressed by OPCs that become rapidly activated in response to injury. By genetic fate mapping, we have been able to show that the Sox2-expressing cells within acute demyelinating lesions are derived from OPCs and not from Sox2-expressing astrocytes. As in developmental myelination, its levels of expression decline as recruited OPCs differentiate into remyelinating oligodendrocytes. Thus, Sox2 shares a pattern of expression with other activation genes such as tcf712, suggesting that it too may be primarily involved in recruitment rather than the differentiation phase of remyelination.

Such a function would be consistent with its role in multipotent neural progenitor cells, where it is required for proliferation, the maintenance of a pan-neural progenitor identity, and the inhibition of differentiation (Bylund et al., 2003; Graham et al., 2003). To test this, we first used undertook a gain-of-function experiment in cultured OPCs, where forced expression led to an inhibition of differentiation. From this, we predicted that a loss of function during either myelination or remyelination would lead to precocious differentiation and premature remyelination. When we used an efficient, inducible constitutive, and cellspecific knock-out approach, we were able to show an impairment of remyelination. This seemed at variance with our hypothesis, but further analysis indicated that the loss of Sox 2 function produced such a profound impairment in OPC recruitment (and increased OPC cell death) that the provision of OPCs became rate limiting, leading to an overall impairment of remyelination. Thus, our data suggest that Sox 2 plays a role similar to that of other differentiation inhibitory transcription factors, including tcf7l2, id2/4, and hes5, and to its role in multipotent neural progenitor cells, where its decreased expression is required for neuronal differentiation (Graham et al., 2003). It is noteworthy that the notch signaling pathway, another inhibitor of oligodendrocyte differentiation during myelination (Wang et al., 1998), is a downstream effector of Sox 2 in neural stem cells (BaniYaghoub et al., 2006). Our conclusions are, however, different from those drawn by Hoffmann et al. (2014), who concluded that Sox2 (and Sox3) are involved in differentiation.

We are not certain how to resolve this apparent discrepancy but suggest that, while Sox 2 plays a role in recruitment, its expression within OPCs may also be required to prime them to differentiate, and that without this priming differentiation is impaired. This is based on the difficulty in inducing OPC differentiation in vitro in the absence of Sox 2 . Such a role may also account for the impairment of remyelination that we found with the Cag-cre$E R^{T 2}$ :Sox $2^{f l / f l}$ mice, where, in addition to reducing OPC recruitment, those OPCs that were present within the lesion were less efficient at becoming new remyelinating oligodendrocytes. The relatively mild phenotype observed in developmental myelination, consistent with the results of Hoffmann et al. (2014) who could find no profound role of Sox2 in perinatal OPCs, contrasted with the results obtained during remyelination. High levels of redundancy are recognized in Sox proteins, especially within oligodendrocyte lineage cells between Sox2 and Sox3. However, the differences between the developmental and regenerative responses to the exclusive loss of Sox 2 suggest that the level of redundancy in Sox2 function and the capacity for compensation by Sox 3 may decline in adulthood. Another explanation is that the inducible Sox 2 knock-out approach used in this study rendered the compensatory effects incomplete compared with germline knockout.

An intriguing observation in our study was the expression of Sox 2 in a proportion of astrocytes in the adult spinal cord. We do not know what the function of Sox 2 is in astrocytes and, using a GFAP-Cre-targeted approach to deplete Sox2 in astrocytes, can find no evidence that it contributes to CNS remyelination, while acknowledging that the Sox 2 expression in astrocytes not captured by this approach may play a contributory role.

The function of Sox transcription family proteins is normally associated with its partner transcription factors (for review, see Kondoh and Kamachi, 2010). The most in-depth studies were performed on Sox2-Oct3/4 interaction in embryonic stem cells, and a number of target genes have been identified. Other examples include Sox2-BRN2 in neural progenitor cells regulating Sox2 and nestin genes (Miyagi et al., 2006), Sox10-BRN2 regulating the Krox20 gene in Schwann cells (Ghislain and Charnay, 2006), and Sox10-Olig1 driving MBP gene expression in oligodendrocytes ( $\mathrm{Li}$ et al., 2007). The identification of Sox2associated genes and the partner factors in OPCs remains an area for future discovery.

\section{References}

Arnett HA, Fancy SP, Alberta JA, Zhao C, Plant SR, Kaing S, Raine CS, Rowitch DH, Franklin RJM, Stiles CD (2004) bHLH transcription factor Olig1 is required to repair demyelinated lesions in the CNS. Science 306:2111-2115. CrossRef Medline

Avilion AA, Nicolis SK, Pevny LH, Perez L, Vivian N, Lovell-Badge R (2003) Multipotent cell lineages in early mouse development depend on Sox2 function. Genes Dev 17:126-140. CrossRef Medline

Bani-Yaghoub M, Tremblay RG, Lei JX, Zhang D, Zurakowski B, Sandhu JK, Smith B, Ribecco-Lutkiewicz M, Kennedy J, Walker PR, Sikorska M (2006) Role of Sox 2 in the development of the mouse neocortex. Dev Biol 295:52-66. CrossRef Medline

Bylund M, Andersson E, Novitch BG, Muhr J (2003) Vertebrate neurogenesis is counteracted by Sox1-3 activity. Nat Neurosci 6:1162-1168. CrossRef Medline

Cahoy JD, Emery B, Kaushal A, Foo LC, Zamanian JL, Christopherson KS, Xing Y, Lubischer JL, Krieg PA, Krupenko SA, Thompson WJ, Barres BA (2008) A transcriptome database for astrocytes, neurons, and oligodendrocytes: a new resource for understanding brain development and function. J Neurosci 28:264-278. CrossRef Medline

Chen XS, Zhang YH, Cai QY, Yao ZX (2012) ID2: a negative transcription factor regulating oligodendroglia differentiation. J Neurosci Res 90:925932. CrossRef Medline

Chew LJ, Gallo V (2009) The yin and yang of Sox proteins: activation and repression in development and disease. J Neurosci Res 87:3277-3287. CrossRef Medline

Emery B (2010) Transcriptional and post-transcriptional control of CNS myelination. Curr Opin Neurobiol 20:601-607. CrossRef Medline

Episkopou V (2005) SOX2 functions in adult neural stem cells. Trends Neurosci 28:219-221. CrossRef Medline

Fancy SP, Zhao C, Franklin RJM (2004) Increased expression of Nkx2.2 and Olig2 identifies reactive oligodendrocyte progenitor cells responding to demyelination in the adult CNS. Mol Cell Neurosci 27:247-254. CrossRef Medline

Fancy SP, Baranzini SE, Zhao C, Yuk DI, Irvine KA, Kaing S, Sanai N, Franklin RJM, Rowitch DH (2009) Dysregulation of the Wnt pathway inhibits 
timely myelination and remyelination in the mammalian CNS. Genes Dev 23:1571-1585. CrossRef Medline

Fancy SP, Chan JR, Baranzini SE, Franklin RJM, Rowitch DH (2011) Myelin regeneration: a recapitulation of development? Annu Rev Neurosci 34: 21-43. CrossRef Medline

Ferri AL, Cavallaro M, Braida D, Di Cristofano A, Canta A, Vezzani A, Ottolenghi S, Pandolfi PP, Sala M, DeBiasi S, Nicolis SK (2004) Sox2 deficiency causes neurodegeneration and impaired neurogenesis in the adult mouse brain. Development 131:3805-3819. CrossRef Medline

Finzsch M, Stolt CC, Lommes P, Wegner M (2008) Sox9 and Sox10 influence survival and migration of oligodendrocyte precursors in the spinal cord by regulating PDGF receptor alpha expression. Development 135: 637-646. CrossRef Medline

Franklin RJM, ffrench-Constant C (2008) Remyelination in the CNS: from biology to therapy. Nat Rev Neurosci 9:839-855. CrossRef Medline

Franklin RJM, Gallo V (2014) The translational biology of remyelination: past, present, and future. Glia 62:1905-1915. CrossRef Medline

Franklin RJM, Crang AJ, Blakemore WF (1991) Transplanted type-1 astrocytes facilitate repair of demyelinating lesions by host oligodendrocytes in adult rat spinal cord. J Neurocytol 20:420-430. CrossRef Medline

Franklin RJ, Crang AJ, Blakemore WF (1993) The role of astrocytes in the remyelination of glia-free areas of demyelination. Adv Neurol 59:125133. Medline

Fu H, Cai J, Clevers H, Fast E, Gray S, Greenberg R, Jain MK, Ma Q, Qiu M, Rowitch DH, Taylor CM, Stiles CD (2009) A genome-wide screen for spatially restricted expression patterns identifies transcription factors that regulate glial development. J Neurosci 29:11399-11408. CrossRef Medline

Ghislain J, Charnay P (2006) Control of myelination in Schwann cells: a Krox 20 cis-regulatory element integrates Oct6, Brn2 and Sox 10 activities. EMBO Rep 7:52-58. CrossRef Medline

Graham V, Khudyakov J, Ellis P, Pevny L (2003) SOX2 functions to maintain neural progenitor identity. Neuron 39:749-765. CrossRef Medline

Harrington EP, Zhao C, Fancy SP, Kaing S, Franklin RJ, Rowitch DH (2010) Oligodendrocyte PTEN is required for myelin and axonal integrity, not remyelination. Ann Neurol 68:703-716. CrossRef Medline

Hirrlinger PG, Scheller A, Braun C, Hirrlinger J, Kirchhoff F (2006) Temporal control of gene recombination in astrocytes by transgenic expression of the tamoxifen-inducible DNA recombinase variant CreERT2. Glia 54:11-20. CrossRef Medline

Hoffmann SA, Hos D, Küspert M, Lang RA, Lovell-Badge R, Wegner M, Reiprich S (2014) Stem cell factor Sox2 and its close relative Sox3 have differentiation functions in oligodendrocytes. Development 141:39-50. CrossRef Medline

Huang JK, Jarjour AA, Nait Oumesmar B, Kerninon C, Williams A, Krezel W, Kagechika H, Bauer J, Zhao C, Baron-Van Evercooren A, Chambon P, ffrench-Constant C, Franklin RJM (2011) Retinoid X receptor gamma signaling accelerates CNS remyelination. Nat Neurosci 14:45-53. CrossRef Medline

John GR, Shankar SL, Shafit-Zagardo B, Massimi A, Lee SC, Raine CS, Brosnan CF (2002) Multiple sclerosis: re-expression of a developmental pathway that restricts oligodendrocyte maturation. Nat Med 8:11151121. CrossRef Medline

Kitada M, Rowitch DH (2006) Transcription factor co-expression patterns indicate heterogeneity of oligodendroglial subpopulations in adult spinal cord. Glia 54:35-46. CrossRef Medline

Kondo T, Raff M (2000) Oligodendrocyte precursor cells reprogrammed to become multipotential CNS stem cells. Science 289:1754-1757. CrossRef Medline

Kondo T, Raff M (2004) Chromatin remodeling and histone modification in the conversion of oligodendrocyte precursors to neural stem cells. Genes Dev 18:2963-2972. CrossRef Medline

Kondoh H, Kamachi Y (2010) SOX-partner code for cell specification: regulatory target selection and underlying molecular mechanisms. Int J Biochem Cell Biol 42:391-399. CrossRef Medline

Leone DP, Genoud S, Atanasoski S, Grausenburger R, Berger P, Metzger D, Macklin WB, Chambon P, Suter U (2003) Tamoxifen-inducible gliaspecific Cre mice for somatic mutagenesis in oligodendrocytes and Schwann cells. Mol Cell Neurosci 22:430-40. Medline

Li H, Lu Y, Smith HK, Richardson WD (2007) Olig1 and Sox10 interact synergistically to drive myelin basic protein transcription in oligodendrocytes. J Neurosci 27:14375-14382. CrossRef Medline
Liu A, Li J, Marin-Husstege M, Kageyama R, Fan Y, Gelinas C, CasacciaBonnefil P (2006) A molecular insight of Hes5-dependent inhibition of myelin gene expression: old partners and new players. EMBO J 25:48334842. CrossRef Medline

Liu J, Casaccia P (2010) Epigenetic regulation of oligodendrocyte identity. Trends Neurosci 33:193-201. CrossRef Medline

Magri L, Swiss VA, Jablonska B, Lei L, Pedre X, Walsh M, Zhang W, Gallo V, Canoll P, Casaccia P (2014) E2F1 coregulates cell cycle genes and chromatin components during the transition of oligodendrocyte progenitors from proliferation to differentiation. J Neurosci 34:1481-1493. CrossRef Medline

McCarthy KD, de Vellis J (1980) Preparation of separate astroglial and oligodendroglial cell cultures from rat cerebral tissue. J Cell Biol 85:890 -902. CrossRef Medline

McKenzie IA, Ohayon D, Li H, de Faria JP, Emery B, Tohyama K, Richardson WD (2014) Motor skill learning requires active central myelination. Science 346:318-322. CrossRef Medline

Miyagi S, Nishimoto M, Saito T, Ninomiya M, Sawamoto K, Okano H, Muramatsu M, Oguro H, Iwama A, Okuda A (2006) The Sox2 regulatory region 2 functions as a neural stem cell-specific enhancer in the telencephalon. J Biol Chem 281:13374-13381. CrossRef Medline

Molofsky AV, Glasgow SM, Chaboub LS, Tsai HH, Murnen AT, Kelley KW, Fancy SP, Yuen TJ, Madireddy L, Baranzini S, Deneen B, Rowitch DH, Oldham MC (2013) Expression profiling of Aldh1l1-precursors in the developing spinal cord reveals glial lineage-specific genes and direct Sox9Nfe211 interactions. Glia 61:1518-1532. CrossRef Medline

Moyon S, Dubessy AL, Aigrot MS, Trotter M, Huang JK, Dauphinot L, Potier MC, Kerninon C, Melik Parsadaniantz S, Franklin RJM, Lubetzki C (2015) Demyelination causes adult CNS progenitors to revert to an immature state and express immune cues that support their migration. J Neurosci 35:4-20. CrossRef Medline

Niu J, Mei F, Wang L, Liu S, Tian Y, Mo W, Li H, Lu QR, Xiao L (2012) Phosphorylated olig1 localizes to the cytosol of oligodendrocytes and promotes membrane expansion and maturation. Glia 60:1427-1436. CrossRef Medline

Pevny LH, Nicolis SK (2010) Sox2 roles in neural stem cells. Int J Biochem Cell Biol 42:421-424. CrossRef Medline

Pohl HB, Porcheri C, Mueggler T, Bachmann LC, Martino G, Riethmacher D, Franklin RJM, Rudin M, Suter U (2011) Genetically induced adult oligodendrocyte cell death is associated with poor myelin clearance, reduced remyelination, and axonal damage. J Neurosci 31:1069-1080. CrossRef Medline

Rivers LE, Young KM, Rizzi M, Jamen F, Psachoulia K, Wade A, Kessaris N, Richardson WD (2008) PDGFRA/NG2 glia generate myelinating oligodendrocytes and piriform projection neurons in adult mice. Nat Neurosci 11:1392-1401. CrossRef Medline

Rosenberg SS, Kelland EE, Tokar E, De la Torre AR, Chan JR (2008) The geometric and spatial constraints of the microenvironment induce oligodendrocyte differentiation. Proc Natl Acad Sci U S A 105:14662-14667. CrossRef Medline

Shen S, Sandoval J, Swiss VA, Li J, Dupree J, Franklin RJM, Casaccia-Bonnefil P (2008) Age-dependent epigenetic control of differentiation inhibitors is critical for remyelination efficiency. Nat Neurosci 11:1024-1034. CrossRef Medline

Sohn J, Natale J, Chew LJ, Belachew S, Cheng Y, Aguirre A, Lytle J, NaitOumesmar B, Kerninon C, Kanai-Azuma M, Kanai Y, Gallo V (2006) Identification of Sox17 as a transcription factor that regulates oligodendrocyte development. J Neurosci 26:9722-9735. CrossRef Medline

Stoffels JM, Hoekstra D, Franklin RJM, Baron W, Zhao C (2015) The EIIIA domain from astrocyte-derived fibronectin mediates proliferation of oligodendrocyte progenitor cells following CNS demyelination. Glia 63: 242-256. CrossRef Medline

Stolt CC, Rehberg S, Ader M, Lommes P, Riethmacher D, Schachner M, Bartsch U, Wegner M (2002) Terminal differentiation of myelinforming oligodendrocytes depends on the transcription factor Sox10. Genes Dev 16:165-170. CrossRef Medline

Swiss VA, Nguyen T, Dugas J, Ibrahim A, Barres B, Androulakis IP, Casaccia $P$ (2011) Identification of a gene regulatory network necessary for the initiation of oligodendrocyte differentiation. PLoS One 6:e18088. CrossRef Medline

Takahashi K, Yamanaka S (2006) Induction of pluripotent stem cells from 
mouse embryonic and adult fibroblast cultures by defined factors. Cell 126:663-676. CrossRef Medline

Takahashi K, Tanabe K, Ohnuki M, Narita M, Ichisaka T, Tomoda K, Yamanaka S (2007) Induction of pluripotent stem cells from adult human fibroblasts by defined factors. Cell 131:861-872. CrossRef Medline

Talbott JF, Loy DN, Liu Y, Qiu MS, Bunge MB, Rao MS, Whittemore SR (2005) Endogenous Nkx2.2+/Olig2+ oligodendrocyte precursor cells fail to remyelinate the demyelinated adult rat spinal cord in the absence of astrocytes. Exp Neurol 192:11-24. CrossRef Medline

Wang S, Sdrulla AD, diSibio G, Bush G, Nofziger D, Hicks C, Weinmaster G, Barres BA (1998) Notch receptor activation inhibits oligodendrocyte differentiation. Neuron 21:63-75. CrossRef Medline

Wegner M (2000) Transcriptional control in myelinating glia: the basic recipe. Glia 29:118-123. CrossRef Medline

Wegner M, Stolt CC (2005) From stem cells to neurons and glia: a Soxist's view of neural development. Trends Neurosci 28:583-588. CrossRef Medline

Woodruff RH, Franklin RJM (1999) Demyelination and remyelination of the caudal cerebellar peduncle of adult rats following stereotaxic injections of lysolecithin, ethidium bromide, and complement/anti-galactocerebroside: a comparative study. Glia 25:216-228. CrossRef Medline

Yang Z, Watanabe M, Nishiyama A (2005) Optimization of oligodendro- cyte progenitor cell culture method for enhanced survival. J Neurosci Methods 149:50-56. CrossRef Medline

Zawadzka M, Rivers LE, Fancy SP, Zhao C, Tripathi R, Jamen F, Young K, Goncharevich A, Pohl H, Rizzi M, Rowitch DH, Kessaris N, Suter U, Richardson WD, Franklin RJM (2010) CNS-resident glial progenitor/ stem cells produce Schwann cells as well as oligodendrocytes during repair of CNS demyelination. Cell Stem Cell 6:578-590. CrossRef Medline Zhang Y, Argaw AT, Gurfein BT, Zameer A, Snyder BJ, Ge C, Lu QR, Rowitch DH, Raine CS, Brosnan CF, John GR (2009) Notch1 signaling plays a role in regulating precursor differentiation during CNS remyelination. Proc Natl Acad Sci U S A 106:19162-19167. CrossRef Medline

Zhao C, Fancy SP, Magy L, Urwin JE, Franklin RJM (2005) Stem cells, progenitors and myelin repair. J Anat 207:251-258. CrossRef Medline

Zhao C, Li WW, Franklin RJM (2006) Differences in the early inflammatory responses to toxin-induced demyelination are associated with the agerelated decline in CNS remyelination. Neurobiol Aging 27:1298-1307. CrossRef Medline

Zhao C, Fancy SP, ffrench-Constant C, Franklin RJM (2008) Osteopontin is extensively expressed by macrophages following CNS demyelination but has a redundant role in remyelination. Neurobiol Dis 31:209-217. CrossRef Medline 